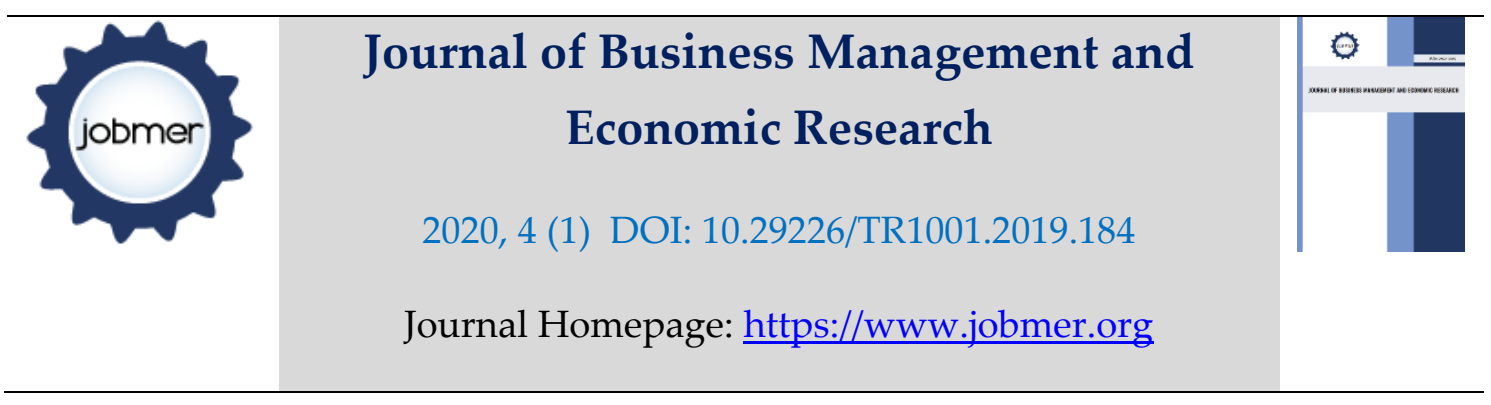

\title{
ADVANTAGES AND DISADVANTAGES OF THE FOUR METHODS OF TAX TREATMENT OF CORPORATE MONETARY AND IN-KIND DONATIONS: A THEORETICAL STUDY OF INTELLECTUAL ENRICHMENT IN THE FIELDS OF TAXATION AND CORPORATE PHILANTHROPIC RESPONSIBILITY
}

\author{
Younis A. Battal Saleh \\ B.Sc.-M.Sc.-CPA-CEA \\ Public Accountant, Expert Accountant and Consultant for Court of Appeal in Benghazi-Libya \\ Lecturer and Researcher in Training Department in HRM of General Electricity Company of \\ Libya "GECOL" In Benghazi-Libya. \\ P.O. Box 18202 Benghazi-Libya -North Africa \\ younisbattal1968@yahoo.com
}

\begin{abstract}
This theoretical study attempted to answer the following question: What are the methods of tax treatment of corporate donations and which method is optimal?. By using new distinctive terms and idioms, this study identified and classified all methods that are expected to be used and that can be used (or actually used) for the tax treatment of corporate monetary and in-kind donations into four main methods, according to the researcher's vision and perception. Those methods are:(1) Method of society's rights and then government's rights (tax exemption in the sense of deduction)" donations as if they are operating expenses; (2)Method of society's rights and then government's rights (tax exemption in the sense of restoration" return\ recovering \retrieval ") " donations as if they are indirect taxes"; (3) Method of government's rights and then society's rights" donations as if they are not granted";(4) Method of government's rights and then corporation's rights in government's rights" donations as if they are loans. The study also identified the advantages and disadvantages of each of the four methods, especially with regard to legal imbalances, economic impacts and the extent of harmony with the content of the idea of corporate social responsibility. By comparing the advantages and disadvantages of these methods, this study recommends the adoption of the method of government's rights and then corporation's rights in government's rights" donations as if they are loans" by legislative bodies in all countries of the world due to the abundance of its advantages. This method is optimal. Given the importance of this method, This study has drawn up a draft law for this method, which could be used as a guide by the legislative bodies, if a decision is made to adopt this method.
\end{abstract}

Keywords: Corporate philanthropy" Corporate social responsibility." Taxation. JEL Classification: M14, H71.

Saleh, Y. A. B. (2020). Advantages And Disadvantages Of The Four Methods Of Tax Treatment Of Corporate Monetary And In-Kind Donations: A Theoretical Study Of Intellectual Enrichment In The Fields Of Taxati On And Corporate Philanthropic Responsibility. Journal of Business Management and Economic Research (JOBMER), Vol: 4, Issue:1, 74-139. 


\section{Introduction}

Usually, the tax treatment of corporate monetary and in-kind donations- in any country, stems primarily from the decision-makers' opinion and law- makers' view about corporate philanthropy. Through this vision, they can identify tax treatment that fits their vision of corporate donations provided by corporations. Such treatment is often associated with a reduction in taxable income. This is the usual treatment in most countries of the world. Definitely will not be the only treatment. Those donations can also be addressed through a reduction in the value of the income tax or a complete disregard for such contributions when determining income tax. In order to achieve a kind of comprehensiveness in this study. It will be necessary to envision all the expected visions of corporate donations. According to the researcher, the visions about corporate donations (interpretation of their meaning and content) cannot exceed one of the following four scenarios: Donations as if they are operating expenses or donations as if they are indirect taxes or donations as if they are not granted or donations as if they are loans. Based on this perception, by using new distinctive terms and idioms, possible methods for the tax treatment of corporate monetary and in-kind donations can be classified into four main methods: Method of society's rights and then government's rights (tax exemption in the sense of deduction)" Donations as if they are operating expenses"; Method of society's rights and then government's rights (tax exemption in the sense of restoration "return\ recovery \retrieval") " donations as if they are indirect taxes"; Method of government's rights and then society's rights" donations as if they are not granted"; Method of government's rights and then corporation's rights in government's rights" donations as if they are loans."

It should be noted that, the prevailing economic conditions in society may directly affect the identification and selection of tax treatment that is appropriate to these circumstances. Economic conditions may be a logical justification for the adoption of any one of the above treatments or for modification of existing laws. Economic conditions may force the government to amend their tax law in the field of treatment of corporate monetary and in-kind donations and grant more tax incentives to donor corporations to urge them to make more contributions to the communities in which they work. 


\subsection{Highlight The Problem}

The problem in this study is intertwined and very interconnected. As a regulatory measure, the researcher divided the problem into two parts: The first part includes the economic and legal effects of tax incentives in return for corporate donations. Also, the impact of those incentives on the content of the corporate social responsibility idea ; The second part includes a statement of how to evaluate the most common method used in the field of tax treatment of corporate monetary and in-kind donations (deducting donations from taxable income).

\subsubsection{The First Part Of The Problem}

This section aims to draw the attention of legislative bodies, economists and specialists in corporate social responsibility to the legal imbalances and economic effects resulting from the granting of tax incentives to corporations for their monetary and in-kind contributions to their communities in which they operate. As well as the impact statement of these incentives on the content of the idea ofcorporate social responsibility.

As is well known, tax treatment of corporate donations is part of the corporate income tax law. Accordingly, the amendment to the income tax law includes a change in the income tax rate applicable to corporations (increase or decrease) or change in the method of tax treatment of corporate donations (by using another method or change the rate of donation deduction in the method actually used) or that the amendment includes income tax rate and the method of tax treatment for corporate donations together. In general, any amendment to the income tax law affects government revenues from taxes, whether the adjustment in the rate of income tax or in the method of tax treatment of corporate donations. These amendments are often the result of the prevailing economic conditions in the country during a period of time.

As a result of the deteriorating economic conditions in many countries. That deterioration accompanied by population explosions, the inability of governments in most of those countries to face their burdens and obligations due to lack of financial resources, the need of those countries to promote economic development and infrastructure in their communities, and with the perception of contemporary societies of the importance of the social role of corporations in the communities in which they work, it was observed in the last few years that, governments in most countries of the world have developed and amended the tax treatment laws for corporate 
monetary and in-kind donations for economic purposes. The striking thing about these amendments is that they contain more tax incentives to encourage corporations to provide more support to their communities in which they operate, by raising discount rates" deduction rates of those contributions from taxable income." The obvious effect of these amendments "tax incentives" is an increase in the amount of tax savings earned by the donor corporations and a decrease in state revenues from taxes. In this regard, the researcher raises three questions on a high degree of importance are:(1) Does granting tax incentives " tax exemptions" to donor corporations contribute to enhancing legal imbalances in the field of tax justice and equity in rights among stakeholders? (2) What are the negative and positive economic effects resulting from the granting of tax incentives to donor corporations?. (3) Is granting tax incentives " tax exemptions" to donor corporations consistent with the content of the corporate social responsibility idea?.

\subsubsection{The Second Part Of The Problem}

This section includes a statement of how to evaluate the most common method used in the field of tax treatment of corporate monetary and in-kind donations (a deduction of the donations from taxable income)by comparing it with all other methods that can be used in the tax treatment of corporate donations, that have been determined by visualizing all expected visions on those donations. In order to achieve this end, all the advantages and disadvantages of all these methods should be determined according to appropriate criteria. In this regard, the researcher raised a set of important questions are:(1) What are all the expected visions about corporate donations that emanates from them tax treatment methods for those donations and, what are the logical justifications upon which these visions depend?.(2) Is there a real harmony between the expected visions of corporate donations and the tax treatment methods derived from those visions? (3) What are the comparison criteria that can be used to identify the advantages and disadvantages of possible tax treatment methods resulting from these visions and perceptions?.(4) What is the optimal tax treatment method that can effectively contribute to the promotion of economic development and infrastructure of the state, reduction the legal imbalances and the achievement a kind of harmony with the content of the corporate social responsibility idea?.(5) What is the method of tax treatment that can contribute to achieving a real harmony between corporate economic responsibility and corporate philanthropic responsibility?. 
Corporate donations can be seen from several angles. Each angle represents a particular perception. These visions are derived from how to interpret the meaning and content of those donations by others(economists; jurists; specialists in financial matters), depending on the analysis of the effects that such donations can produce. Donations can be envisioned as if they are operating expenses. The idea of this perception stems from the following justification: In the modern era, in developed countries, donations contribute indirectly to improving the economic performance of corporations by gaining the loyalty and satisfaction of employees, consumers, investors and the community, especially in communities that recognize the importance of corporate social responsibility. Donations are the price of survival and continuity of corporations in those communities in which they operate as a result of the depletion of their resources and the export of miscellaneous damage to those communities. In contemporary societies, such expenditures (voluntary contributions) are becoming increasingly necessary without them those corporations will not be able to enhance their position in the markets of these communities" as one of the requirements of competitive advantage acquisition." These expenditures will not contribute to the increase in the number of units produced by corporations - such as production expenditures, but may contribute to the increase in the volume of sales (or maintain the same market share) as a result of consumer loyalty to their products. Those consumers are aware of the importance of the growing social role of corporations in the communities in which they work" the importance of corporate philanthropy in contemporary societies," and thus they support these corporations by buying their products. Donations can be envisioned as if they are indirect taxes. The idea of this perception stems from the following justification: The government uses the money earned from corporate taxes to finance public sector expenditures in order to provide services to its citizens, as well as to finance various development programs, including the strengthening of infrastructure in the country, that benefit the public interest. Donations made by corporations to their communities also contribute to the promotion of economic and social development in their countries and contribute to solving many social issues of certain communities in their societies. These donations have a positive impact in field of the service of the common good. Therefore, donations can be considered as indirect taxes provided by corporations to their communities without mediation the government in the process of receiving and re- spending. Ignoring these expenditures may create a state of double taxation, which includes two types of taxes are contributions "indirect taxes" and income taxes "direct taxes." Ignoring means paying two kinds of taxes "direct and indirect." Donations can be envisioned as if they are not granted. The idea of this perception stems from the following justifications: 
Donations are expenditures that have nothing to do with the economic activity of corporations. In other words, they do not contribute directly to achieving the profit. Donations are voluntary activities and are not economic activities. These charitable acts should be completely ignored when determining taxable income. Not to ignore these expenditures will contribute to harming the government by reducing its tax revenues. Corporate Social Responsibility (CSR) does not mean giving benefit to a party at the expense of another. Corporate social responsibility means achieving justice among all stakeholders. As is known, donations are often given to non-profit organizations or charities, with the aim of providing assistance to specific communities or to addressing special issues. In this case they are not to support the vital expenditures of the government. When donations are made to nonprofit organizations or charities, the claim that these donations should be ignored will be justified. Those charitable acts - in these areas, must be borne by donor corporations and not the government. Justice must be achieved in rights among the donor corporation, the government, and the beneficiaries of such donations. The interest of the donor corporation and the beneficiaries of the donation should not be at the expense of the government. As a result of these contributions, the corporation may gain the tax savings resulting from those contributions and government will bear the burden of the decline in the volume of its income from taxes, so this result will be considered unfair to the government. As well as, Donations may be the entrance to pass many unethical practices and behaviors. Ignoring those donations will prevent those practices and behaviors. Donations can be envisioned as if they are loans. The idea of this perception stems from the following justifications: Taxes represent government rights in corporate profits. Any obligations paid by the corporation on behalf of the government must be returned to corporation by reducing the value of taxes due to the government. The non-return of these contributions to donor corporations means covering up the government's failure to manage its affairs, including the search for financial resources other than taxes(corporate donations may contribute to the emergence of a surplus in the state budget. This surplus does not reflect the effectiveness and efficiency of the government in the management of state affairs. It will hide behind it a fake performance) . Corporations must not bear the failure of governments to develop their annual revenues from the diverse sources. Spending on public sectors and government bodies and strengthening the infrastructure of the state is the competence of the government, it is not the competence of corporations. That spending must be financed from taxes or sources other than corporate donations. Although the financing of public sector institutions and the strengthening of the infrastructure in the state in order to improve the public services provided to citizens is a part of the burden, obligations and responsibilities of the 
government - which must be financed from its annual revenues, but corporate donations can be one of the sources of government revenues that can be used to finance those expenditures. Sometimes the governments are unable to finance their public institutions "public spending", in addition to financing the process of strengthening the infrastructure in the country. For this reason, these governments resort to stimulate corporations to make more financial contributions to them by using the tax incentive system. These incentives are only evidence of the need for the funds (donations). The corporate donations used to support government spending are only the payment of government obligations on behalf of the government. In this sense, why are not corporate donations considered voluntary loans?. Accurate analysis will show that there is a hidden lending relationship. Pay with your right hand " donations" and take with your left hand" tax incentives." Commitment vs. commitment. The sacrifice by governments of a portion of their tax revenues for donor corporations suggests that there is a lending process that disappears behind those donations. There is a commitment to donate and there is an obligation to give incentives. This is very similar to the lending process, even if the full amount is not recovered.

Another justification to support this perception is that governments are not non-profit organizations or charities that are funded by corporate donations. Therefore, those donations must be returned to donor corporations and considered as loans. Donations should be given to organizations and institutions that do not have financial resources, and that rely on the charity of others. This does not mean that governments should not accept corporate donations. The intended meaning of this perception lies in tax treatment and not in the acceptance or nonacceptance of such donations by the government. Those donations should be seen as loans, that should be returned to donor corporations.

Based on these visions and perceptions, the researcher identifies all tax treatment methods that cannot exceed the following four methods: Method Of Society's Rights And Then Government's Rights (Tax Exemption In The Sense Of Deduction)" Donations As If They Are Operating Expenses; Method Of Society's Rights And Then Government's Rights (Tax Exemption In The Sense Of Restoration"Return"). Donations As If They Are Indirect Taxes"; Method Of Government's Rights And Then Society's Rights" Donations As If They Are Not Granted"; Method Of Government's Rights And Then Corporation's Rights in Government's Rights" Donations As If They Are Loans." 
The most used method in most countries of the world is the tax treatment that allows the deduction of corporate donations from taxable income" with the difference in discount rates among those countries." Method of society's rights and then government's rights (tax exemption in the sense of deduction)" donations as if they are operating expenses." This method motivates corporations to make donations because it allows the granting of tax incentives to donor corporations. The questions posed by the researcher, is this law or tax treatment optimal or not? In other words, does this method contribute to the promotion of economic development and infrastructure in the country?. Does this method suffer from legal imbalances?. Is this method in tune with the content of CSR idea?. These questions can only be answered after evaluating all the methods that are expected to be used and that can be used (or actually used) for the tax treatment of corporate monetary and in-kind donations by studying their economic effects, legal imbalances and their impact on the content of the idea of corporate social responsibility. And to this end, the idea is to visualize all the methods that are expected to be used and that can be used (or actually used) for the tax treatment of corporate monetary and in-kind donations that could be used in comparison processes. Here, the following question can be raised, what criteria can be used in the comparison process?. The problem raised by this theoretical study in this part lies in the following questions: What are the legal imbalances associated with the tax treatment methods of corporate donations?. What are unethical practices can be passed through these methods?. What are the economic effects that these methods can produce?. Do specialized legislative bodies in the field of issuing corporate income tax laws take into account the impact of tax treatment of corporate monetary and in-kind donations on the real content of the idea of CSR when making laws or not?. In other words, Are the laws issued by legislative bodies" enacted legislation in the area of tax treatment for donations" in line with the content of the CSR idea?. How can this be explained" compatibility between tax treatment methods and the content of the idea of CSR?. Do the laws aim to encourage corporations to incur such expenditures without taking into account the content of the CSR idea or are they to consolidate the CSR's high principles such as achieving justice in rights, combating of immoral behaviors and the rejection of opportunism. etc.?. Where all tax treatment methods have an impact on the core of CSR idea, but with an interpretation and philosophy differ from one method to another. The specialized legislative bodies in the field of issuing corporate income tax laws in all countries of the world must be aware of the impact of laws"enacted legislation in the field of tax treatment of corporate monetary and in-kind donations" on the content of the CSR idea. These bodies must be fully informed of the impact of 
their laws" enacted legislation" on the content of the CSR idea. To achieve this, these bodies can rely on the content of the controversy that will be raised by the researcher in this study.

\subsection{Objectives of The Study}

The objectives of this theoretical study can be defined in the following points:

(1) Identification of potential" possible" methods that can be used for tax treatment of corporate monetary and in-kind donations; (2) Defining the advantages and disadvantages "positive and negative effects" of the methods of tax treatment for corporate monetary and in-kind donations. In other words, to identify the legal imbalances, the economic effects resulting from these methods and the extent of the harmony of these methods with the content of the idea of corporate social responsibility; (3) The differentiation among tax treatment methods for corporate monetary and in-kind donations and determining the optimal method according to legal and economic considerations. That optimal method that can also safeguard the content of the idea of corporate social responsibility and develop it.

\subsection{The Importance Of Studying}

By specifying all the advantages and disadvantages of all tax treatment methods for corporate monetary and in-kind donations, the legislative bodies and economists in any country can know the shortcomings of the methods used to address such donations in their countries. The results of this theoretical study will contribute to providing the opportunity for legislative bodies and economists in different countries of the world to evaluate the laws in force to address the corporate donations and then choose the appropriate method for the conditions of their countries. Where knowledge of the economic effects and legal imbalances of all methods of tax treatment, as well as the unethical practices and behaviors that can be passed through these methods by the donor corporations, and the extent of harmonization of tax treatment methods with the content of the idea of corporate social responsibility will help in determining the optimal method to adopt

it as a law in the state.

\subsection{Methodology Of The Study}

This study focuses on identifying the advantages and disadvantages that can be inferred from the tax treatment methods of monetary and in kind donations, which can be relied upon to generate controversy, and that can contribute to justifying support or rejection of any of these methods. To achieve that, the method used in the analysis and dialectical dialogue will be relying 
on hypothetical numbers of the income statements that can simulate reality, which can be treated according to the methods used in the process of calculating corporate income tax in the case of monetary and in kind donations, and comparing the results to identify and deduce the advantages and disadvantages of these methods. The researcher selected three criteria for comparison are: Economic impact; Legal imbalances; The extent of closeness to, or distance from the content of the idea of corporate social responsibility. Through these criteria, the advantages and disadvantages of each method can be identify

\section{LITERATURE REVIEW}

\section{1. The Corporate Social Responsibility (CSR )}

The idea of CSR is nothing new. The new is the evolution that has occurred in the content of its thought over time. Social Responsibility of corporations - which means the need to conduct business in a socially responsible manner, evolved from an era of philanthropic initiatives to an era of strategies and policies that meet the needs and ambitions of the communities in which they operate. CSR was no more than philanthropic initiatives by employers to help workers and the poor. And with the emergence of trade unions and social pressures, corporations began to pay attention to improving working conditions. With the emergence of competition among corporations and consumer protection organizations, corporations have been and continue to pay great attention to the consumer protection. And with the growing phenomenon of environmental pollution which is caused by industrial processes, and the emergence of environmental protection organizations, As well, political and social pressures, corporations have begun to contribute seriously to environmental protection. Last but not least, and with the emergence of sustainable development ideas, corporations have become aware of the importance of achieving their objectives in accordance with the requirements of sustainable development, which takes into account the rights of living of present and future generations on Planet Earth.

The charity provided by the employers to the poor and their employees in the past centuries has had a great impact on the emergence of CSR thought. Among the general public, there is still confusion between the concept of Philanthropic responsibility and CSR; the first is considered one of the components of the second, it contributed to its development. Development does not only include the concept of CSR, but also encompassed the concept of philanthropy - as one of its components, to transform from a mere practice into an effective strategy. 
From philanthropy to strategic philanthropy: This notion contends that organizations should find social needs that align with their particular expertise (or core competencies). For example, it would seem to make little sense for a computer manufacturer to spend funds on building homeless shelters. This is not to suggest that the computer manufacturer should not engage in philanthropy, but rather that when it does so, it should engage in an activity or issue closer to its area of expertise. Companies that focus on the causes in their area of expertise will almost certainly be more efficient at addressing social needs (Wyk, 2011:65).

There are many definitions of CSR with similar meanings. In this study, the researcher has developed a definition that includes almost all those meanings. The researcher defines CSR in its general sense as follows: Corporate Social Responsibility (CSR) means exercising economic activities (by corporations) with legal guidance and ethical behavior, when achieving their desired goals that ensure the growth and continuity for them. Taking into account compliance with the following requirements: Contributing to the continuation of life and improving its quality, and achieving prosperity on the planet Earth for present and future generations; not to inflict material and moral damage on others, and serious interaction with them to achieve common interests, and belief that they are a important and irreplaceable part to ensure the process of their continuation and achievement of their objectives; Commitment to everything that makes life organized in the environment in which they work.

\subsection{Corporate Philanthropic Responsibilities}

If a company is able to meet all of its other responsibilities (Economic, Legal and Ethical), it can begin meeting philanthropic responsibilities. Philanthropic responsibilities are responsibilities that go above and beyond what is simply required or what the company believes is right. They involve making an effort to benefit society - for example, by donating services to community organizations, engaging in projects to aid the environment or donating money to charitable causes (Scilly,n.d).

The philanthropic responsibilities are the voluntary responsibilities of the enterprise. They reflect the current expectations of the public towards the enterprise. These volunteering activities are animated only by the desire of the enterprise to involve itself in community activities which are not imposed or requested by law and which generally are not to be expected from an enterprise, 
in an ethical way. The public expects that an enterprise should involve in philanthropic actions and thus this category becomes a part of the social agreement between the enterprise and the society. Such activities can include donations of goods and services, volunteering activity, the involvement of the enterprise or of its employees in the community or of the stakeholders. Philanthropy includes those corporate actions which answer to the society's expectations, according to which the enterprises are good corporate citizens. This includes the efficient commitment in actions or programs of promoting the welfare or the human good will (Grigore, 2010: 170; Carroll, 2016: 4).

The researcher defines Philanthropic responsibility as a component of CSR as follows: it is a set of the initiatives that includes philanthropic "material and non-material donations" that contribute to improving the quality of life within the communities in which they operate, which is voluntarily provided by corporations without any legal coercion, in response to the aspirations of contemporary societies and their urgent desires to develop the role of corporations to be the ideal partner who will bear part of their worries and problems due to the inability of governments - in most countries of the world, to meet all the needs of their contemporary societies and achieve all their aspirations.

\subsection{Population Explosion And Increasing Government Burdens}

In modern times, and in light of the population explosion in most countries of the world, and the scarcity of economic resources and the growing burden of the government in the face of contemporary challenges, foremost of which are to achieve the economic well-being of their communities, improve the standard of living of their citizens, and enhance the security and integrity of their lands. Governments are no longer able to finance all development projects, strengthen infrastructure, meet contemporary challenges, meet the aspirations of their people at the same time, and with the same economic resources available. It was necessary to have a reliable partner, which could contribute to shoulder part of the burden of those governments. That partner is the private sector" corporations ", by adhering to its social responsibility towards the community in which it operates, as a result of the depletion of its economic resources and the damage to its material and moral components by that sector in order to achieve its economic gains. Therefore, both corporations and governments should contribute to the achieving well-

being and improving the quality of life of their communities. No one can achieve this alone. 


\subsection{Classification Of The Corporate Social Expenditures}

The researcher used a legal compulsion and accountability criterion in the classification process (Is there a legal accountability about them in the event of spending stopping or no?). Therefore, for the purposes of this study, the researcher classified the social expenditures into two types are: (Saleh, 2018:84-85).

\subsubsection{Mandatory Social Expenditures (MSEs)}

There is a legal accountability about them in the event of spending stopping. There are some social expenditures incurred by corporations - in some areas of social activities, as a result of legal commitment to a prevailing law and regulations in the state. Therefore, all corporations will incur those expenditures, no option for rejecting. These expenditures cannot be avoided as a result of accountability and legal compulsion. Also, stop the spending will expose the corporation to penalties and fines and in many cases to stop the activity, such as the contribution of Libyan corporations in the payment of subscriptions of the social security for employees (In Libya, corporations and staff contribute to the payment of those subscriptions, for the benefit of staff, according to the Libyan social Security Act.), salaries for families of the missing people and dead in the wars, expenditures to treat work-related injuries and medical insurance, protection expenditures of the environment and consumer,and security and safety of employees expenditures, etc. Therefore, the researcher defines the MSEs as follows: MSEs are mandatory, cannot be avoided, there is a legal accountability about them in the event of stop the spending, can directly affect corporation economic performance through the penalties and fines or stop of the activity.

\subsubsection{Non - Mandatory Social Expenditures (N-MSEs)}

This type can be classified into two types: (A) N-MSEs in areas unrelated to interact with the community: This type may affect the loyalty of consumers and workers, and then on the economic performance of the corporation. There are some social expenditures incurred by the corporations - in areas of CSR (workers, environment, consumer), without any legal compulsion and accountability (this depends on the nature of the industry, the environment in which the corporation operates and the prevailing laws ).Those expenditures can be avoided. Also, stopping of the spending will not expose the corporation to penalties and fines or stopping 
of the activity, but they may affect the corporate economic performance, through the change in the level of consumer loyalty to the corporation 's product - where consumer is one of important stakeholders of the corporation, and a loyalty of the employees to the corporation, especially in developed countries and in the presence of competition in our modern age, such as expenditures of the improvement of the working environment, product development, transport means, training of workers and staff, child custody, and free food and drinks for workers, etc. Therefore, the researcher defines the N-MSEs in areas unrelated to interact with the community as follows: N-MSEs are necessary, not voluntary and not mandatory, can be avoided, there is no legal accountability about them in the event of stopping of the spending, may indirectly and directly affect the economic performance of the corporation in the presence of market competition (in the market of labor, goods and services) through the change in the level of consumers and employees loyalty - at present, the consumer becomes more aware of issues of CSR, and consumers ' decisions are becoming increasingly influenced by the extent of corporation's commitment to its social responsibility. Also, a loyalty of the employees to the corporation has a direct impact on its economic performance. According to Keeler, competition is the primary driver for corporations to be more socially responsible ( Keeler 2002 : Kasipillai and Rachagan,2012:1).This is as a result of the competition in the market of labor, goods and services. In the modern era - especially in developed countries- consumer loyalty depends largely on the extent of the corporation's commitment to its social responsibility. Where the consumer has become more aware of the issues of social responsibility, such as boycotting the products that are not environmentally friendly. As well as, the completion of the business has become dependent on the skill and knowledge of the workers, in order to earn their loyalty and maintain them as part of a working system, corporations incur social expenditures such as free food and drinks for the workers, etc. (B) NMSEs in the areas of interaction with the community (Corporate Philanthropy): This type is voluntary and similar to government spending in the field of public services. Corporations incur this kind of expenditures in order to contribute to the improvement of the quality of life in the community and to assume the role of government in this area. This type is intended in this study. There are some social expenditures incurred by the corporations- in the area of interaction with the community, without any legal compulsion. These expenditurescan be avoided. Also, stopping of the spending will not expose the corporation to penalties and fines or stopping the activity, such as the expenditures of contribution in educating people in the area, contribution in cleaning public gardens and helping of poor families, etc. Therefore, the researcher defines the N-MSEs in this area as follows: N-MSEs are non-mandatory, can be avoided, there is no a legal 
accountability about them in the event of stopping of the spending. Mostly, they affect the corporate economic performance through the acquisition of some incentives and tax benefits or other economic benefits- especially in the developed countries, through the satisfaction of society and government, and loyalty of consumers there. Where consumers and communities who are aware of the importance of the social role of corporations. In developing and poor countries, where there is the high level of ignorance among people, the spread of poverty and the deterioration of living conditions, the researcher believes that the consumer will be interested in the quality and price of the goods without regard to the extent of the corporation's commitment to its social responsibility. While in developed countries, there may be interest by consumers in such matters. Where consumer loyalty may affect the corporation's economic performance. The impact of social responsibility on profitability remains the subject of debate among scientists until this moment. Absolutely, this depends on the environment in which the corporation operates and the extent of consumer understanding and awareness. Regardless of any other benefits (competitive advantage, tax incentives, etc.) which can be achieved and are difficult to measure and trace, the users of the financial statements and reports will care about the actual figures paid and not the positive effects that are difficult to track them. Therefore, classification into two types - mandatory and non-mandatory, is a logical proposition for the purposes of this study. Tax savings are related to expenditures that do not result in legal sanctions against the corporation in the event of stopping of the spending, regardless of their impact on economic performance. For example, the tax authority does not pay special attention to the free meals expenditures of the corporation's employees, despite its importance to the employees and the positive effects of the corporation, although they are not mandatory, but they are not related to interaction with society issues, they may be more related to the economic performance of the corporation. While the tax authority is interested in charity (corporate philanthropy), because it embodies the real interaction between corporation and society, when determining the tax incentives.

\subsection{Corporate Philanthropy" Corporate Giving / Corporate Donation"}

Philanthropy is a term connected with the American tradition of charitable giving. At first it was associated with a person- philanthropist, but today the term corporate philanthropy is more developed, meaning business sector's voluntary giving (Mihaljević and Tokić, 2015 : 804). Philanthropy stems from the Greek word which means love of humanity. Popular interpretations today refer to private initiatives for public good (J. W. Gardner) or initiatives directed at the improvement in the quality of human life (Robert Bremner). Colloquially, philanthropy is most 
commonly used interchangeably with charitable giving. - WINGS (John et al., 2017: 136 ). Corporate philanthropy is the act of corporations donating a portion of their profits or resources to various non-profit organizations (Madrakhimova, 2013:125). This definition may be consistent with the laws in some countries that require the payment of donations to nonprofit organizations to prevent fraud and deception. This definition is limited, it excludes direct donations to poor people, completion of some public projects such as building schools and hospitals, etc. as well as non-material help for the public good" volunteer work ", unless the laws of the State so require, where the public interest so requires. Here, nonprofits will play the role of mediator. Another definition is: The use of discretionary financial and human resources for primarily public benefit, while recognizing that impact might also accrue for the company's shareholders and employees (John et al., 2017: 133 ). The researcher defines corporate philanthropy (corporate giving or corporate donation) as follows: It is all material donations" money, assets and goods" and nonmaterial "services ", which are provided to nonprofit organizations or the poor and the needy or for the public good to improve the quality of life in the community. This may result in the achievement benefits for corporations such as exemptions and tax incentives, in addition to enhancing the competitive advantage. There is increasing interest by corporations in their philanthropic responsibility, especially in developed countries, where many studies have shown that corporate giving has been on the rise in recent years. For example, a study on corporate donations in the United States in 2005 has shown that 62 biggest companies in the U.S. gave $\$ 8.4$ billion last year, an increase of $14 \%$ from 2004 . Also, $87 \%$ of the companies surveyed indicated that they have an employee volunteer program, with $44 \%$ of them offering paid time off to employees who volunteer (Man, 2006:1; Perry, 2006). The global survey of CSR spending over the period 2011 - 2013 by Dattani et al. (2015) revealed that the top 10 most generous companies worldwide gave US\$ 17.7 trillion towards CSR spending annually. An estimated 28 percent of this sum (nearly US\$5 trillion) was in the form of grants rather than in-kind donations or volunteering (John et al. ,2017: 18 ).

\subsubsection{What Might Be Hidden Behind The Corporate Monetary And In-Kind Donations?}

Donations may be a stone for more than a bird "more than a purpose." They may hide behind them many unwanted behaviors, in addition to legitimate purposes. The purpose of the donation 
depends on the intentions of the donor. In general, donations can be a tool to achieve the following purposes:

\subsubsection{Embezzlement "Collusive Embezzlement"}

Donations may be used as a means of embezzlement through the collusion of both the management of the corporation and the recipient of the donations" a charity $\backslash$ charitable organization". This unethical behavior occurs as a result of the following factors: (1) Separation of ownership from management; (2) A malicious administration manages the affairs of the corporation; (3) Weak internal and external control systems; (4) Excessive trust given to management.

\subsubsection{Tax Evasion}

It can be achieved through subsidies received by individuals, charities and NPOs for false declarations of charitable donations. Taxpayers in many developed countries can deduct donations to charities from their income tax and reduce their tax liabilities by reporting higher cash or gift donations (e.g. clothes, cars) to charities than they have actually made, and thus evade income tax (Nell, n.d.:7). Donations of the corporations may be one of the tools of economic crimes such as tax evasion and smuggling of money, etc. In Russia, the law was far imperfect, as stated by many educated people in the issues of taxation. In the early 2000s, the government began to deal with this state of affairs as a result of the abolition of many benefits for donors. Before a period of directing up to $5 \%$ of their income to charity, this legislation establishes that donation by firms and organizations can only occur at the expense of net profit. The Ministry of Finance has decided that companies providing charitable activities through the provision of free services or delivery of goods are exempted from VAT, but payments to the state treasury is not reduced. In order to avoid the transfer of funds through bogus charities against government charity, double taxation was introduced. According to the Tax Code of the Russian Federation, donation recipients have to pay income tax, but people can avoid it if they obtain grant in the field of education, science, culture and art (Madrakhimova, 2013: 128). On 5 December 2015, Al-Sharq AlAwsat published an article entitled" Donations by America's billionaires: Are they donations or tax avoidance?". This article discussed the suspicions surrounding the America's billionaires, the policy of "giving by the right hand and taking by the left hand" and the economic benefits that will be gained by those billionaires (Al-Kholi,2015). 


\subsubsection{Political Gains}

The donation for the purpose of political gains is an acquisition of the influence of the government and its administrative agencies, and use that influence in order to pressure the government to make decisions in favor of the donor corporations. Philanthropy may be a way for political businessmen to gain power, where their charitable work will help to show them as good men who are good at managing their country's affairs. Bertrand et al in their study in 2018 in the USA, their empirical results implied that 8.8 percent of corporate charitable giving is politically motivated.

\subsubsection{Tax Incentives}

In many countries, charitable contributions benefit from a favorable tax treatment that may take the form of a deduction from taxable income or of a tax credit. Recently, these tax incentives have been further promoted by the governments of several European countries, as a way to increase private funding for fields like education, research and culture(Fack and Landais,May 2010:117)."Charitable giving by individuals and businesses is an important source of funding for nonprofit organizations. These charitable donations are influenced by various factors. For donors in the state of Michigan." Some of the more common reasons to give to nonprofits are to help others, to support an organization or cause they believe in, and felt it is morally obligatory to contribute." While these factors vary for each individual or business, research indicates that tax implications influence the size of the donation. Donors receive economic benefit from a reduction in the amount of paid taxes. The motivation to reduce taxes by contributing to a nonprofit is known in economic terms as a tax incentive. The most common tax incentives are either tax deductions or tax credits, as in USA "(Enders, n.d). In developed countries, governments have recognized the importance of donations to charities or nonprofit organizations in solving many social problems and also to encourage corporations to continue their noble activities. Many taxrelated laws have been reformed and improved in those countries, while in other countries especially in developing countries - claims are still increasing the need to amend the tax laws to be consistent with charity. The United Kingdom, the United States, Canada and Australia, since the beginning of their income tax regimes, have all permitted a deduction or tax credit for gifts to certain public purpose organizations. In the last decade all these countries have used policy measures such as nonprofit fundraising capacity building, publicity campaigns and tax 
incentives to encourage philanthropy (Lyons and Passey 2006 ;McGregor-Lowndes et al, 2006:496).

\subsubsection{Competitive Advantage}

Increasingly, philanthropy is used as a form of public relations or advertisement to promote a company's image or brand through cause related marketing or other high-profile sponsorshipsarguing that "social and economic goals are not inherently conflicting, but integrally connected (Porter and Kramer, 2002: 1). Whereas, philanthropy can be a source of competitive advantage (Porter and Kramer, 2002: 1; Henderson and Malani, 2008: 7).

\subsubsection{Improving The Quality Of Life}

Corporate philanthropy is a key component of a corporation's broader social responsibility, and includes cash gifts, product donations, and employee volunteerism. It serves as a major link between the corporation and its communities. Corporations support their communities in numerous ways-foundation giving, providing local volunteers, donating goods and services, and even pro bono assistance (without charge). Corporations work hard to help improve the quality of life in their communities and have a strong sense of responsibility to the people in their communities (JA Worldwide \online). Donations provided by corporations to non-profit organizations are often used to achieve the following goals: (1) Contributing to solving the social problems of certain categories of people within communities such as orphans, elders, alcoholics and drug abusers, etc.(2) Economic assistance to the poor and needy within communities.(3) Combating some negative phenomena within societies and correction of deviant behaviors.(4) Supporting public attitudes and issues that are in the interest of society.(5) Supporting public awareness and educational programs on some issues within societies.(6) Combating all types of pollution "environmental / moral / noise, etc ." resulting from economic and technical developments.(7) Completing some other projects such as construction, maintenance and development which are in the interest of society. Certainly, these achievements will contribute to improving the quality of life within these communities.

\subsubsection{Distracting The Attention Of The Public Opinion On A Particular Issue}

Through charitable donations and using excessive media propaganda, some corporations try to distract the public opinion about some of the scandals and immoral practices they have 
committed, or due to the nature of harmful products produced by those corporations" such as the tobacco and alcohol industry," or as a result of environmental damage caused by those corporations, , in order to alleviate the anger of the public towards those corporations in an attempt to convince the public that they are good citizens, their benefits for the society " financial support provided by them " are more than their harms.

\subsubsection{To Reduce Or Avoid Losses Resulting From Obsolescence Or Expiration Of Inventory}

When the inventory (products/machines/ materials, etc.) expiration date is close to completion, or when the inventory is outdated due to the emergence of new models "as in clothes," corporations will try to get rid of it with the least amount of economic losses, by donating the stock and achieving tax savings.

\subsection{INCOME TAX AND CSR}

Income tax is a key source of funds that the government uses to fund its activities and serve the public. That funds of the taxes are part of the revenues of the state government, without that funds the government cannot manage the state affairs. As is well known, the government uses that funds to paystaff salaries in the public sector, constructing of the schools, hospitals, roads , bridges, and parks, etc. Therefore, corporations must be committed to supply" pay " the values of taxes to the tax administration" tax authority." That commitment comes from the reality of the legal responsibility of corporations to the community and its institutions. Also, non-compliance with tax laws and tax evasion by corporations means facing sanctions in accordance with the law of the State's economic crimes." Academics have advocated including the paying of taxes in CSR. For example, the American professor Avi-Yonah adamantly maintains that companies bear a social responsibility that includes loyally paying taxes. He also argues in favor of companies refraining from business transactions whose sole objective is to minimize taxes" (Avi-Yonah,2014; Svernlöv, 2016:8). On the contrary, in recent years, there have been calls for the development of tax laws on corporate income in many countries of the world. This calls for the need to change the Laws to conform to the strengthening requirements of the idea of practice of CSR by corporations through the creation of a system of incentives to achieve tax justice among the corporations and contributes to encouraging corporations to adopt the idea of social responsibility. For example, Jordanian Al Rai newspaper published an article on 18 - 112014 under the title" The private sector calls for legislation to stimulate the adoption of the idea 
of CSR."Also, there were some actual initiatives in many countries aimed at reforming tax systems, for example, tax reform in France in 2003 about incentives for corporate giving \ corporate philanthropy (Lordemus,2013 :16). The Sudaress website published an article in 2013 under the title "Donations for Taxes". This article was an invitation to the Sudanese government to develop the tax code to encourage taxpayers to donate as is the case in the United States. This article stressed the need to find a law that allows deducting the contributions of corporations and businessmen from the taxes imposed on them(Sudaress,2013). In order to encourage taxpayers to contribute to charity and community service. In 2017, the Sultanate of Oman carried out tax reforms "Amendment to the Tax Code" under Royal Decree No. 9/2017. Those reforms included tax treatment of donations. In kind donations are as costs, that must be deducted when determining taxable income. Those amendments were as incentives for donors (Ministry of Finance \General Secretariat of Taxation "Sultanate of Oman",2017).

\subsubsection{Content Of The Idea Of CSR}

The idea of CSR includes many lofty principles, including but not limited to the following: The fight against all forms of corruption, fraudulent practices and unethical behaviors such as tax evasion, deception and fraudulence "Pay with your right hand and take with your left hand." Achieving justice in rights among all stakeholders. CSR means promoting freedoms and rights, supporting human and economic development, and contributing to improving the standard of living, economic well-being and infrastructure development in societies. The corporations ' purpose of the commitment to social responsibility should be to enhance their competitive advantage by gaining the satisfaction and loyalty of society and government, consumers, investors, etc. Corporations take their resources from the communities in which they operate, and often those communities are affected by the damage produced by those corporations. Corporations will be obliged to compensate those communities. Donations and loans are part of that compensation. It is not within the content of the idea of CSR to gain economic benefits out of the scope of the competitive advantage. If this problem" defect " occurs, the CSR will lose its meaning and lofty principles.

\subsection{Tax Treatment Methods Of Corporate Monetary And In-Kind Donations:}


Corporate income tax laws differ from country to country, especially with regard to how the tax treatment of monetary and in-kind donations incurred by corporations. In fact, all tax laws in this area cannot be studied for all countries of the world. According to the researcher's vision and perception, all laws (the tax treatments of monetary and in-kind donations) could not go beyond one of the following four scenarios: (1) Method Of Society's Rights And Then Government's Rights (Tax Exemption In The Sense Of Deduction). Donations As If They Are Operating Expenses;(2)Method Of Society's Rights And Then Government's Rights (Tax Exemption In The Sense Of Restoration "Return") . Donations As If They Are Indirect Taxes"; (3) Method Of Government's Rights And Then Society's Rights. Donations As If They Are Not Granted ( Saleh,2019:1-15) ; (4) Method Of Government's Rights And Then Corporation's Rights In Government's Rights. Donations As If They Are Loans.

\subsubsection{Method Of Society's Rights And Then Government's Rights (Tax Exemption In The Sense Of Deduction). Donations As If They Are Operating Expenses.}

This method is one of the most widely used methods in most corporate income tax laws. It is widely used in many countries of the world. This method is used as a tool to motivate corporations to make more and more donations. This is the only method through which tax incentives can be given to donor corporations. According to this method, corporate monetary and in-kind donations are considered as expenditures which must be deducted from revenues (according to the deduction rate: where the rate of deduction varies from state to state) to determine taxable income. Tax exemption, according to this method is in the sense of deduction" reduction," and not in the sense of restoration" return." The value of such donations shall not be excluded from the total expenditures value "in accordance with the granted tax exemption rate", with no any tax exemptions in the sense of restoration"return." This method allows deducting the value of monetary and in-kind donations from the value of revenue to determine the value of taxable income and the value of the tax invoice, if certain conditions are met in those donations, according to the tax law in force in the State. In other words, deduction of community rights" donations" from revenue and then deduction of income tax" government's rights" from that residual income. The intended tax exemption is to reduce the value of the tax invoice by reducing taxable income by the value of monetary and in-kind donations.

\subsubsection{Method Of Society's Rights And Then Government's Rights (Tax Exemption In The}

Sense Of Restoration "Return") . Donations As If They Are Indirect Taxes. 
This method is one of the proposed scenarios "perceptions," as a method that can be used in the area of tax treatment of corporate donations.Here the exemption is in the sense of restoration" return" and not the in the sense of deduction" reduction. " This method is similar to the previous method and the difference between the two methods lies in the interpretation of the meaning of tax exemption. For this method, corporate monetary and in-kind donations are considered as indirect taxes that must be returned to the donor corporation by reducing the value of the tax invoice by the value of those donations- according to certain conditions, with a view to returning those donations to donor corporations to avoid double taxation. According to this method, community rights" value of donations " must be deducted from the value of the income tax" the tax invoice"- "according to the deduction rate", what remains of the value of that invoice will be considered as the rights of the government. The intended tax exemption is to refund "return" the value of the donations to the donor corporation before paying the tax invoice to the tax authority.( The deduction of donations must be from the value of the tax invoice "income tax" and not from the value of the revenue "or taxable income").

\subsubsection{Method Of Government's Rights And Then Society's Rights. Donations As If They Are}

\section{Not Granted.}

According to the principle of non-confusion" non-mixing" between the rights of stakeholders "government and society."This method pays no attention to monetary and in-kind donations, and it does not grant any tax exemptions. According to this method, donations are deducted from income after tax" Shareholders' equity or distributable income". As taxable income and income tax would be calculated without taking into account such donations. Those donations are deducted from the distributable income after determining the tax value or tax invoice.

\subsubsection{Method Of Government's Rights And Then Corporation's Rights In Government's}

\section{Rights. Donations As If They Are Loans.}

This method is similar to the method of society's rights and then government's rights (tax exemption in the sense of restoration "return": donations as if they are indirect taxes) ,however, the difference between the two methods lies in the interpretation of the nature of the donation, the method of return(how to return donations to donor corporations), the expected vision on voluntary contributions and the philosophy of understanding their meanings. According to this method, donations must be made by corporations in the areas of government spending and not in the area of assistance of nonprofit organizations and charities. As for the return of donations 
to donor corporations, donations must be returned in full to the donor corporations in installments, that must be deducted from annual income taxes of donor corporations. Donations, according to this method, can be considered as loans to support the government that must be returned to the donor corporations in batches" in installments."

\subsection{Tax Exemption, Tax Saving And The Real Sacrifice}

\subsubsection{Conditions For Recognition Of Corporate Monetary And In-Kind Donations And Granting Tax Exemption.}

Most legislative bodies in most countries of the world try to develop their texts and articles in the field of income tax law, specifically in the area of corporate donations treatment, to limit the use of those donations as a means of tax evasion or other illegal purposes, and to achieve a kind of tax justice among taxpayers. As a result, most legislative bodies in the field of taxation have designed a package of procedures and conditions under which the donation process is recognized, as well as to grant tax exemption for such contributions. What distinguishes these conditions is that they are almost identical in the tax systems in most countries of the world. To obtain the recognition of donations and the granting of tax exemption in exchange for those contributions, tax systems in many countries of the world require certain conditions, for example: In accordance with the tax law of the Arab Republic of Egypt(Income Tax Law No. 91 of 2005 and its amendments).(1) Contributions paid to the Government, local government units and other public legal persons are recognized regardless of their amounts as the deductible cost (of taxable income) ; (2) Donations and subsidies paid to accredited Egyptian NGOs," scientific institutions, scientific research institutions and hospitals" subject to government supervision, must be deducted (of taxable income) according to the following conditions; (3) That such contributions and subsidies have already been paid;(4) These donations and subsidies shall be paid to Egyptian charitable societies, which shall be recognized in accordance with the provisions of the laws governing them; (5) The value of these contributions shall not exceed 10/110 of the net adjusted tax profit of the Company (the amount of contributions paid or 10/110 of the net adjusted tax profit, whichever is less). Any donations or other subsidies than the foregoing are not recognized as deductible costs such as donations to the poor of the neighborhood or to an unrecognized charity or victims of Afghanistan or to the Mujahideen/ fighters of Palestine, etc. ( 
Egyption Tax Authority ). According to the tax law of the Syrian Republic(Law No. 24 of 2003 on Income Tax), Article 7 provides that: Expenditures/ donations that can be deducted from nonnet profits are voluntary contributions paid by taxpayers to officially recognized public or private entities" according to official receipts" to achieve public benefits , Provided that both donors and the recipient have an accounting system and regular books accepted by the income tax departments, not exceeding 3\% of net profits( General Commission For Taxes And Fees). The Irish tax system contains a range of incentives aimed at facilitating and encouraging charitable giving by individuals and companies, which help to ensure that charities receive the maximum benefit from public and private donations. Tax relief is available for donations by both individuals and companies provided: there is a donation of money or of shares, stock or debentures of a class quoted on a recognized stock exchange, the recipient is either an "eligible charity" or another approved body, there is no arrangement that the donation can be repaid, neither the donor nor anyone connected with the donor benefits from the donation, the donation does not depend on and is not conditional upon the acquisition of property by the charity otherwise than by way of a gift from the donor, an individual donor is resident in Ireland (corporate donations may be made by branches of foreign companies in Ireland), and the minimum donation in any year to any one eligible charity or approved body is $€ 250$ (Charitable giving guide,2017:5). In accordance with the Canada Revenue Agency, A gift is a voluntary transfer of property for which the donor receives no benefit in return. For there to be a gift, the following conditions must be met: the donor transfers ownership of property (cash, or gifts in kind such as goods or land) to a registered charity; the transfer is voluntary; and no benefit is provided to the donor, or a person selected by the donor, unless the benefit is of nominal value (Canada Revenue Agency,n.d.:7).

Here it should be noted that, there is a difference between tax exemption in the sense of reduction and tax exemption in the sense of restoration \return. In the first status: Exemption means the inclusion of the value of donations in the list of expenditures to be deducted from the value of revenues to determine the taxable income from the point of view of the tax authority. In the second status: Exemption means the reduction of the value of the tax invoice at the value of such donations or part thereof," the exemption is in the sense of restoration \return, not a reduction, it means calculating taxable income and determining the value of the tax invoice while ignoring donations at this stage, and then reducing the value of the invoice by the amount of that donations or part of them." It is a very rare condition, or it does not exist \use in fact, but will remain one of 
the proposed treatment methods, which may serve as an incentive for taxpayers to continue to incur such expenditures. In fact, most countries in the world have designed a package of conditions that must be met in order to recognize the validity and integrity of the donation activities, as a precautionary measure against corruption. They also design set of the conditions for the granting of tax exemptions for such contributions, which are often different from one country to another in accordance with the tax laws of each country.

\subsubsection{The Difference Between Net Accounting Income And Net Tax Income"Taxable}

\section{Income"}

Net accounting income represents the result of the corporation's activity over a specified period (accounting period), which is calculated according to accepted and recognized principles, assumptions and accounting methods. While net tax income or taxable income represents the corporation 's income for that period in accordance with the applicable tax laws in the country. It is for the purpose of determining the value of the tax invoice payable. Net accounting income is often adjusted to meet calculation requirements of the income tax according to the IRS's view and tax law in the country.

\subsubsection{Tax Saving And The Real Sacrifice:}

Social expenditures" donations " incurred by the corporations - which seek to achieve the profitsat the end of the accounting period are treated as other expenditures for the purpose of determining the value of the taxable income- in accordance with the traditional accounting approach - where donations contribute to reducing the value of the income tax that will be paid to the fiscal administration according to the law and tax regulation used in the State. Also, the non-mandatory social expenditures (in the field of corporate philanthropy) may contribute to achieving some tax reliefs (tax exemptions) for corporations. This incentive will lead to a reduction in the value of income tax- which must be paid to the IRS. As it's known, donations are financial amounts incurred by the corporation for the purpose of contributing to the achievement of the social benefits for other parties in the society - within the framework of mutual benefits and the corporation. Thus, these expenditures will not contribute to producing the income nor achieving any directly economic benefits to these corporations such as the contribution of other expenditures (general and administrative expenditures, distribution and sale expenditures, manufacturing expenditures, etc.). Although social expenditures" donations" differ from the 
other expenditures incurred by the corporations in terms of the goal of the spending process, however, the accounting treatment of these expenditures in the income statement - for the purpose of determining taxable income - is not different from the treatment of other expenditures, according to the traditional accounting approach and the method of society's rights and then government's rights (tax exemption in the sense of deduction). As it is shown in the income statement, those expenditures are excluded from the value of revenues (income statement for the purpose of determining the taxable income and economic performance). Generally, this treatment lead to a reduction in the value of taxable income resulting from such expenditures incurred by the corporation during the accounting period, and then a decrease in the value of the income tax paid to the fiscal administration. If the corporation did not incur any non-mandatory social expenditures" donations" during the ended accounting period, the value of the taxable income and the value of the income tax paid to the fiscal administration would be higher than the value of the taxable income and the value of the income tax paid to the fiscal administration in case the corporation incurred non-mandatory social expenditures during the ended accounting period. That is to say that, according to the hypothetical comparison, the corporation which incurs nonmandatory social expenditures will pay an income tax less than what will be paid, if it does not endure non-mandatory social expenditures. As a result of this, the corporation achieves a tax saving as a result of decreasing in the value of the taxable income resulting from the value of the non-mandatory social expenditures" donations."

Tax saving is (The value of the tax must be paid to the fiscal administration under the assumption that the corporation did not incur any non-mandatory social expenditures" donations during the ended accounting period) - (The value of the tax must be paid to the fiscal administration in the case that the corporation incurred non-mandatory social expenditures" donations" during the ended accounting period). Tax saving resulting from donations can be defined as follows: It is the amount of the decrease in the value of the income tax paid by the corporation to the fiscal administration on a definite financial period as a result of incurring non-mandatory social expenditures during that period. Also, it can be defined as the difference in value resulting from comparing the value of the income tax paid to the fiscal administration - under the assumption, that the corporation did not incur any non-mandatory social expenditures during the ended accounting period -with the value of the income tax paid to the fiscal administration in the case that the corporation incurred non-mandatory social expenditures during the ended accounting 
period. The hypothetical comparison method is used to indicate the paid amounts with the right hand and the collected amounts with the left hand. (Saleh, 2018:85). The Real Sacrifice is the difference between the value of monetary and in-kind donations and the value of tax savings.

The Real Sacrifice $=$ The Monetary And In-Kind Donations - Tax Savings.

\subsubsection{Types Of Tax Exemption For Donations}

It is often misunderstood the meaning of tax exemption in exchange for monetary and in-kind donations. The tax exemption may be for the purpose of reduction" in taxable income" or for the purpose of restoration "return" through the final tax invoice, which is calculated without taking into account any donations " - according to the legal text. Both "reduction and restoration "return" contribute to the reduction of the value of the tax invoice payable. But they differ in meaning and method of calculation. As a result of this similarity, the researcher sees the need to define the difference between the two terms in order to remove the state of ambiguity. As the deduction means a reduction in the value of taxable income by the amount of donations or part of them. In other words, donations (or part thereof) are treated as other expenditures in the statement of income to determine the net accounting income, which represents the taxable income. While restoration" return" means reducing the value of the tax invoice" which is calculated without taking into account any donations" by the value of such monetary and in-kind donations(or part thereof). To address the exemption in the sense of restoration" return," according to this method, donations are deducted directly from the value of the income tax" from the value of the initial tax invoice without the need to deduct donations from revenue or the value of taxable income" (The final tax invoice, which is calculated without taking into account any donations = the initial tax invoice" income tax" - donations or part of them). For example, assuming that: A corporation submitted its following financial data to the IRS for the payment of income tax for the fiscal period of last year. Revenue $\$ 100,000$; Total expenditures $\$ 20,000$; Monetary donations to government organizations $\$ 10,000$. What is required: A statement of how to calculate the value of tax exemption in the sense of deduction and tax exemption in the sense of restoration" return." Value of taxable income. Knowing that, donations are deducted in full; Income tax rate is $20 \%$. What is required can be determined in the following two tables No.1 and No.2. 
2.8.4.1. First: Tax exemption in the sense of deduction "deducting the value of donations from the value of revenues."

\begin{tabular}{|c|c|c|}
\hline A statement & $\begin{array}{c}\text { Assuming that the } \\
\text { corporation did not incur any } \\
\text { donations during the past } \\
\text { year }\end{array}$ & $\begin{array}{c}\text { The tax exemption in the sense of } \\
\text { deduction, under the assumption } \\
\text { that the corporation incurred } \\
\text { donations during the past year }\end{array}$ \\
\hline Revenues & $\$ 100000$ & $\$ 100000$ \\
\hline Expenditures & $\$ 20000$ & $\$ 20000$ \\
\hline Donations & $\$ 80000$ & $\$ 10000$ \\
\hline Taxable income & $\$ 16000$ & $\$ 140000$ \\
\hline Income Tax "Tax & & $\$ 2000$ \\
invoice value" & & \\
\hline $\begin{array}{c}\text { Tax savings }(\$ 16000- \\
\$ 14000)\end{array}$ & & \\
\hline $\begin{array}{c}\text { A real } \\
\text { sacrifice }(\$ 10000- \\
\$ 2000)\end{array}$ & & \\
\hline
\end{tabular}

Table (1): How to calculate the tax exemption in the sense of deduction and also determine the value of tax savings and real sacrifice.

2.8.4.2. Second: Tax exemption in the sense of restoration" return." Deducting the value of donations from the value of income tax" the value of the initial tax invoice."

\begin{tabular}{|c|c|}
\hline \multicolumn{2}{|c|}{ The tax exemption in the sense of restoration"return" } \\
\hline A statement & Value \\
\hline Revenues & $\$ 100000$ \\
\hline Expenditures & $\$ 20000$ \\
\hline Taxable income & $\$ 80000$ \\
\hline $\begin{array}{c}\text { Income tax before deducting the donations" the value of the initial } \\
\text { tax invoice" }\end{array}$ & $\$ 16000$ \\
\hline Donations & $\$ 10000$ \\
\hline
\end{tabular}


The value of the final tax invoice

$\$ 6000$

Table (2): How to calculate the value of the tax exemption in the sense of restoration" return."

Through the data listed in the two tables above, it can be said that, the income tax "tax invoice value" is $\$ 14,000$ when the tax treatment method is tax exemption in the sense of deduction " reducing the taxable income value by the value of donations, thus reducing the value of the tax invoice." While in the second case, the income tax "tax invoice value" is $\$ 6,000$ when the tax treatment method is tax exemption in the sense of restoration"return," reducing the income tax value by the value of donations, thus reducing the value of the tax invoice."

\subsection{Advantages And Disadvantages Of The Four Methods Of Tax Treatment Of Corporate} Monetary And In-Kind Donations

All previous methods have advantages and disadvantages. Especially in the field of achieving tax justice and equity in rights among stakeholders. To adopt one of these methods to be used in the treatment of monetary and in-kind donations in any country depends on the point of view of the legislative body and its philosophy about donations and the extent of its understanding of the idea of CSR and economic conditions prevailing in the state.

\subsubsection{Comparison Criteria}

To determine the advantages and disadvantages of tax treatment methods, one must first find a set of logical criteria. These criteria will be used to infer"conclude" the advantages and disadvantages of those methods. The researcher has identified three criteria that can be used in comparison operations for evaluation purposes and for extracting advantages and disadvantages of those methods. Those criteria are:

\subsubsection{Economic Impact}

This criterion refers to the extent to which the tax treatment method of corporate monetary and in-kind donations contributes to the promotion of economic development and infrastructure development in the country in an effective manner. As well as a statement of the positive or negative impact on government revenues from taxes, the market value of the shares of the donor corporations and shareholders' equity. 


\subsubsection{Legal Imbalances}

This criterion refers to the legal imbalances that can be produced by the tax treatment method of corporate monetary and in-kind donations such as double taxation, failure to achieve tax justice among corporations and failure to achieve justice in rights among all stakeholders affected by such treatment "government, society, investors, etc."

\subsubsection{The Extent Of Closeness To, Or Distance From The Content Of The Idea Of Corporate Social Responsibility}

This criterion refers to the extent of harmony between the tax treatment method of corporate monetary and in-kind donations and the content of the idea of social responsibility and its supreme principles. In other words, the contribution of the method of tax treatment in reducing or preventing the phenomenon of tax evasion, the practice of unethical behavior, and opportunistic behavior by corporations. As well as, achieving justice in rights.

The idea of CSR has come into existence in order to create a greater role for corporations in their communities, and fruitful interaction between those corporations and their communities in which they operate. Those communities, through which such corporations obtain their economic resources, market their products, on the other hand, those corporations are exporting their damages to those communities. That role, that transcends the barriers of their traditional role of maximizing profits and gains. This does not mean that corporations will not achieve any economic benefits by adhering to their social responsibility, on the contrary, corporations can achieve economic benefits by adhering to their social responsibility, but the only way to reach that goal is through gaining the competitive advantage, which can be created by that commitment. Competitive advantage can be achieved through the loyalty and satisfaction of employees, consumers, society, government and investors. That loyalty and satisfaction can be gained through a corporate commitment to their social responsibility. In the modern era, workers, consumers, society, government and investors have become more aware of the importance of corporate commitment to their social responsibility, where they have an influential role in the issue of the economic gains that corporations seek to achieve through competitive advantage. 
They have become the pillars of competitive advantage, through which economic gains are achieved.

CSR means not waiting for any economic benefits, except for those benefits that are achieved by competitive advantage. The competitive advantage is to promote the economic situation of corporations, and any other gains that CSR can achieve them, should not be on the list of corporate aspirations. CSR is not a means to achieve the economic gains outside the competitive advantage.

CSR means devotion, the sincerity of the intentions, and great loyalty in commitment, not pretending the commitment for misleading propaganda purposes in accordance with the policy of giving with the right hand and taking with the left hand through a detestable opportunistic behavior. CSR does not mean providing benefits to a particular community at the expense of another community. In other words, not to provide benefits to a particular sect"group" that would cause damage to another sect.

CSR means achieving justice in rights. CSR means keeping away from opportunistic behavior. CSR means not to exploit legal gaps to achieve economic gains. CSR means not to deceive public opinion, even if it is legally permissible. Where data and information should be disclosed in accordance with transparency standards. CSR is a thought that embraces all lofty meanings that oppose all unethical behaviors and practices and tools that contribute to the spread of those behaviors and practices.

\subsubsection{What Is New About Corporate Philanthropic Responsibility?}

One of the common mistakes in the field of CSR is that people are used to understanding CSR in the field of interaction with the community as donations to charities and nonprofit organizations without waiting for the restoration of those expenditures by the donor corporations or with some positive achievements"such as tax incentives." The content of the idea of corporate philanthropic responsibility means contributing to the achievement a real revolution in the field of economic development and infrastructure within society, the method used to achieve that end is not important, as long as it is legitimate. Loans are a type of financial contribution that corporations 
make to their communities in which they operate, which can be included in the list of corporate philanthropic responsibilities. Financial assistance in the form of loans contributes to creating a harmony between corporate economic responsibility (safeguarding the economic resources of the donor corporation) and corporate philanthropic responsibility (contribution to the creation of real economic development and infrastructure development in the communities in which they operate).

The content of the corporate social responsibility idea is still under development. It does not mean stagnation but rather the search for the best trends that corporations can take in order to fulfill their social responsibility towards their communities. Accordingly, it is possible to say that governments and legislative authorities - in any country in the world, must look for the best ways to make corporations truly contribute to the development of their communities in which they operate and at the same time maintain their economic potential. This means the necessity to create a kind of harmony between the corporate economic responsibility and the corporate philanthropic responsibility. One of the common misconceptions about the concept of corporate social responsibility is to consider donations as the only evidence to prove that corporations interact with the issues and aspirations of the communities in which they operate. The interaction between corporations and the community can be in the form of loans rather than donations that weaken the economic capabilities of corporations. If this the perception "scenario" happens which refers to adopting the idea of lending instead of the idea of giving or donation, it can be said that, there is a state of harmony between the corporate economic responsibility and the corporate philanthropic responsibility. Where the growth of the corporation 's economy is a growth of the state economy or society. The content of the idea of corporate social responsibility (CSR) means the effective contribution of corporations to the creation of real economic development and the enhancement of infrastructure in the communities in which they operate, regardless of the method or approach taken to achieve this the purpose. This argument raised by the researcher may be a cornerstone for developing the concept of corporate interaction with the aspirations and issues of the societies in which they operate- in the future. The contribution of corporations "financial assistance" may be in accordance with the approach of giving or lending approach. In the second case, it can be said that corporations are committed to their economic responsibility (strengthening their economic potentials), at the same time,they are committed to their philanthropic responsibility towards their societies. Adopting the idea of lending instead of the 
idea of giving or donation means commitment to CSR in a rational way. The new in the field of corporate philanthropic responsibility lies in changing the policy of interaction with society " transition from donation policy to lending policy." The new policy aims to create a kind of harmony between corporate philanthropic responsibility and corporate economic responsibility. This change should be supported by the development of income tax laws. Especially in the area of tax treatment of corporate spending in the field of interaction with the aspirations of the community to support economic development and infrastructure.

\subsubsection{A Hypothetical Example}

This is a hypothetical example for the purpose of explaining how the tax treatment of monetary and in-kind donations. Certainly, the results and their effects (negative and positive) will vary according to the rates of deduction or restoration "return" that may be high or low, according to the legal texts and the vision of the legislative bodies in the state. In order to explain the content of the idea of tax treatment and create a meaningful dialogue about it, the researcher assumes that the rates of deduction or restoration "return" are 100 percent. If the deduction rate falls" decreases" below 100 percent in the Method Of Society's Rights And Then Government's Rights (Tax Exemption In The Sense Of Deduction). It means that the tax treatment will include the two methods "treatments " are the Method Of Society's Rights And Then Government's Rights (Tax Exemption In The Sense Of Deduction) and Method Of Government's Rights And Then Society's Rights." Without a doubt, the impact" results" of a method of tax treatment of donations will be affected by the discount rate" exemption rate", amount of taxable income before deducting donations, and amount of donation"

Assuming that there are three corporations specialized in the manufacture of milk are "X, Y, Z ". The three corporations have the same market share, the same economic power, and they use the same technology in manufacturing processes. The following table " as in table No(3)" represents the data and information taken from the financial statements and accounting books of those corporations.

\begin{tabular}{|l|l|}
\hline A Statement & Corporations \\
& \\
\hline
\end{tabular}




\begin{tabular}{|c|c|c|c|}
\hline & X & Y & Z \\
\hline Revenues & $\$ 600000$ & $\$ 600000$ & $\$ 600000$ \\
\hline Expenses Without Donations & $\$ 200000$ & $\$ 200000$ & $\$ 200000$ \\
\hline Donations Recognized By The Tax Authority & $\$ 50000$ & $\$ 150000$ & \\
\hline Number of shareholders "Number of shares" & 1000 & 1000 & 1000 \\
\hline Manpower "Number of Employees" & 200 & 225 & 230 \\
\hline
\end{tabular}

Table (3) The data and information taken from the financial statements and accounting books of three corporations.

For the sake of the accuracy of the comparisons and the logical arguments that will be raised, the researcher will assume the consistency" symmetry" of data and information regarding the value of revenues and expenses without donations and the number of shareholders. It is the policy of the three corporations to distribute half of the profits after taxes to shareholders. The income tax rate is $30 \%$ of the taxable income. In the case of tax incentives, assume that contributions are fully deducted if the method used is" Method Of Society's Rights And Then Government's Rights." Also, assuming that donations are deducted from income tax in equal installments over five years if the method used is the Method Of Government's Rights And Then Corporation's Rights In Government's Rights. The donations were to support the government in order to develop the country's infrastructure. Through the data and information mentioned above, it is possible to determine the impact of different methods of tax treatment on the government, society, corporations, shareholders and the content of the idea of corporate social responsibility," in other words, the determination of the advantages and disadvantages of tax treatment methods," depending on the language of the numbers, as in table No (4):

\section{Effect Of Tax Treatment Methods}

\begin{tabular}{|c|c|c|c|}
\hline \multicolumn{3}{|c|}{ Income Taxes Under The Assumption That There Are No Voluntary Contributions } \\
\hline \multirow{2}{*}{ A Statement } & \multicolumn{3}{|c|}{ Corporations } \\
\cline { 2 - 4 } & $\mathrm{X}$ & $\mathbf{Y}$ & $\mathrm{Z}$ \\
\hline Revenues & $\$ 600000$ & $\$ 600000$ & $\$ 600000$ \\
\hline Expenses & $\$ 200000$ & $\$ 200000$ & $\$ 200000$ \\
\hline Taxable Income & $\$ 400000$ & $\$ 400000$ & $\$ 400000$ \\
\hline
\end{tabular}


Journal of Business Management and Economic Research (JOBMER), vol.4, issue.1, pp.74-139

\begin{tabular}{|c|c|c|c|}
\hline Income Tax Payable To The Tax Authority & $\$ 120000$ & $\$ 120000$ & $\$ 120000$ \\
\hline Net Income After Taxes & $\$ 280000$ & $\$ 280000$ & $\$ 280000$ \\
\hline Increase In Value Of Assets & $\$ 140000$ & $\$ 140000$ & $\$ 140000$ \\
\hline Distributable Income " Profit " & $\$ 140000$ & $\$ 140000$ & $\$ 140000$ \\
\hline Distributed Earnings Per Share & $\$ 140$ & $\$ 140$ & $\$ 140$ \\
\hline \multicolumn{4}{|c|}{$\begin{array}{l}\text { Method Of Society's Rights And Then Government's Rights } \\
\text { (Tax Exemption In The Sense Of Deduction) }\end{array}$} \\
\hline Revenues & $\$ 600000$ & $\$ 600000$ & $\$ 600000$ \\
\hline Expenses & $\$ 200000$ & $\$ 200000$ & $\$ 200000$ \\
\hline Donations Recognized By The Tax Authority & $\$ 50000$ & $\$ 150000$ & \\
\hline Net Accounting Income & $\$ 350000$ & $\$ 250000$ & $\$ 400000$ \\
\hline Net Tax Income "Taxable Income " & $\$ 350000$ & $\$ 250000$ & $\$ 400000$ \\
\hline Value Of Tax Invoice"income tax" & $\$ 105000$ & $\$ 75000$ & $\$ 120000$ \\
\hline Distributable Income " Profit " & $\$ 122500$ & $\$ 87500$ & $\$ 140000$ \\
\hline Increase In Value Of Assets & $\$ 122500$ & $\$ 87500$ & $\$ 140000$ \\
\hline Distributed Earnings Per Share & $\$ 122.5$ & $\$ 87.5$ & $\$ 140$ \\
\hline Tax Savings Resulting From Donations & $\$ 15000$ & $\$ 45000$ & \\
\hline $\begin{array}{c}\text { The Real Sacrifice" The Real Value Of } \\
\text { Donations " }\end{array}$ & $\$ 35000$ & $\$ 105000$ & \\
\hline \multicolumn{4}{|c|}{ Compulsory Partnership } \\
\hline Government Share & $\$ 15000$ & $\$ 45000$ & \\
\hline Share Of The Corporation & $\$ 35000$ & $\$ 105000$ & \\
\hline \multicolumn{4}{|c|}{$\begin{array}{l}\text { Method Of Society's Rights And Then Government's Rights } \\
\text { ("Tax Exemption In The Sense Of Restoration" Return") }\end{array}$} \\
\hline Revenues & $\$ 600000$ & $\$ 600000$ & $\$ 600000$ \\
\hline Expenses & $\$ 200000$ & $\$ 200000$ & $\$ 200000$ \\
\hline Net Accounting Income & $\$ 400000$ & $\$ 400000$ & $\$ 400000$ \\
\hline Taxable Income & $\$ 400000$ & $\$ 400000$ & $\$ 400000$ \\
\hline
\end{tabular}


Journal of Business Management and Economic Research (JOBMER), vol.4, issue.1, pp.74-139

\begin{tabular}{|c|c|c|c|}
\hline $\begin{array}{l}\text { Value Of Tax Invoice" Income Tax "'Before } \\
\text { The Amendment" }\end{array}$ & $\$ 120000$ & $\$ 120000$ & $\$ 120000$ \\
\hline Donations Recognized By The Tax Authority & $\$ 50000$ & $\$ 150000$ & \\
\hline The Value Of The Final Tax Invoice & $\$ 70000$ & $(\$ 30000)$ & $\$ 120000$ \\
\hline $\begin{array}{c}\text { Income After Tax Adjustment" Revenues-( } \\
\text { Expenses+ The Final Value Of The Tax } \\
\text { Invoice)" }\end{array}$ & $\$ 330000$ & $\$ 400000$ & $\$ 280000$ \\
\hline Distributable Income " Profit " & $\$ 165000$ & $\$ 200000$ & $\$ 140000$ \\
\hline Increase In Value Of Assets & $\$ 165000$ & $\$ 200000$ & $\$ 140000$ \\
\hline Distributed Earnings Per Share & $\$ 165$ & $\$ 200$ & $\$ 140$ \\
\hline Refunds In The Future "Tax Exemptions" & & $\$ 30000$ & \\
\hline DONATIONS AS IF THEY ARE NOT GRANTED & \multicolumn{3}{|c|}{ Method Of Government's Rights And Then Society's Rights } \\
\hline Revenues & $\$ 600000$ & $\$ 600000$ & $\$ 600000$ \\
\hline Expenses & $\$ 200000$ & $\$ 200000$ & $\$ 200000$ \\
\hline Net Accounting Income & $\$ 400000$ & $\$ 400000$ & $\$ 400000$ \\
\hline Taxable Income & $\$ 400000$ & $\$ 400000$ & $\$ 400000$ \\
\hline Value Of Tax Invoice" Income Tax" & $\$ 120000$ & $\$ 120000$ & $\$ 120000$ \\
\hline Donations & $\$ 50000$ & $\$ 150000$ & \\
\hline Income After Tax And Donations & $\$ 230000$ & $\$ 130000$ & $\$ 280000$ \\
\hline Distributable Income " Profit " & $\$ 115000$ & $\$ 65000$ & $\$ 140000$ \\
\hline Increase In Value Of Assets & $\$ 115000$ & $\$ 65000$ & $\$ 140000$ \\
\hline Distributed Earnings Per Share & $\$ 115$ & $\$ 65$ & $\$ 140$ \\
\hline \multicolumn{4}{|c|}{$\begin{array}{l}\text { DONATIONS AS IF THEY ARE LOANS } \\
\text { Method Of Government's Rights And Then Corporation's Rights In Government's Rights }\end{array}$} \\
\hline Revenues & $\$ 600000$ & $\$ 600000$ & $\$ 600000$ \\
\hline Expenses & $\$ 200000$ & $\$ 200000$ & $\$ 200000$ \\
\hline Net Accounting Income & $\$ 400000$ & $\$ 400000$ & $\$ 400000$ \\
\hline Taxable Income & $\$ 400000$ & $\$ 400000$ & $\$ 400000$ \\
\hline
\end{tabular}


Journal of Business Management and Economic Research (JOBMER), vol.4, issue.1, pp.74-139

\begin{tabular}{|c|c|c|c|}
\hline $\begin{array}{c}\text { Value Of Tax Invoice" Income Tax "'Before } \\
\text { The Amendment" }\end{array}$ & $\$ 120000$ & $\$ 120000$ & $\$ 120000$ \\
\hline $\begin{array}{c}\text { Donations Recognized By The Tax } \\
\text { Authority" annual installment" }\end{array}$ & $\$ 10000$ & $\$ 30000$ & \\
\hline $\begin{array}{c}\text { The Value Of The Final Tax Invoice } \\
\text { Expenses+ The Final Value Of The Tax } \\
\text { Invoice)" }\end{array}$ & $\$ 110000$ & $\$ 90000$ & $\$ 120000$ \\
\hline $\begin{array}{c}\text { Income After Tax Adjustment" Revenues-( } \\
\text { Distributable Income " Profit " }\end{array}$ & $\$ 290000$ & $\$ 310000$ & $\$ 280000$ \\
\hline Increase In Value Of Assets & $\$ 145000$ & $\$ 155000$ & $\$ 140000$ \\
\hline Distributed Earnings Per Share & $\$ 145$ & $\$ 155$ & $\$ 140$ \\
\hline Refunds In The Future "Tax Exemptions" & $\$ 40000$ & $\$ 120000$ & \\
\hline
\end{tabular}

Table (4) Methods of tax treatment of monetary and in-kind donations.

\subsubsection{Advantages And Disadvantages Of Tax Treatment Methods For Monetary And In-Kind}

\section{Donations:}

Through the results shown by the calculations in the hypothetical example above, and the nature of these methods, a set of advantages and disadvantages can be devised for each method of tax treatment for monetary and in-kind donations. Some disadvantages and advantages can be observed through the numbers in the previous table, and others that will depend on the depth of the logical arguments that will be raised by the researcher.

\subsubsection{Firstly: Donations As If They Are Operating Expenses: Method Of Society's Rights}

\section{And Then Government's Righ (Tax Exemption In The Sense Of Deduction).}

If the value of tax incentives increases, the value of the economic gains of the donor corporations will increase and the value of the government's tax revenues will decrease by an amount of those gains. Therefor, the level of gains and damages will depend on the amount of these incentives.

\section{The Disadvantages Of This Method}

(1) This method contributes to reducing state tax revenues. This decline in revenue may confuse the government in the completion of its plans and programs in the field of promoting economic 
development and infrastructure in the country, in addition to continuous spending on its institutions and government bodies. Donations may be given to charities and non-profit organizations, and thus will not contribute directly to supporting the plans and programs of economic development and strengthening of infrastructure in the country. The benefits of these donations will be intended to support a particular community, such as orphans and the poor, and will not have public benefits that benefit all members of society. According to the researcher's view, donations should be given as support to the government "for government-funded institutions and bodies, and development programs in the country." Donations to charities and non-profit organizations contribute to the reduction of government revenues from taxes without having a significant impact on the promotion of economic development and infrastructure in the country. Donations should not be made in a random way. Donations must be subject to government guidance and control. Funding of charities and non-profit organizations must be through other communities within the community, such as employees in the public and private sectors, in accordance with the social solidarity approach within contemporary societies.

(2) This method contributes to creating what can be called a mandatory" Compulsory" partnership between the government and the donor corporations. Donations will be funded by government and donor corporations. The amount of decline in the value of government revenues from taxes (tax savings achieved by the donor corporations) will represent the amount of the government's contribution to those donations, which may be granted to charities and non-profit organizations, which may not directly contribute to the promotion of economic development and infrastructure in the state due to the reduction of government revenues from taxes. In addition, this partnership may contribute to creating confusion in the planning of public expenditure in the state and thus change the fiscal policies of government spending.

(3) This method contributes to achieving the tax savings for the donor corporations. This method may be used as a tool to reduce economic losses in inventory by donating obsolete inventory" obsolete stock" or inventory whose validity period is nearing completion, in order to achieve tax savings that contribute to reducing the amount of economic damage resulting from the obsolete inventory and the validity or expiration dates of the product " validity of inventory usage in the coming period." This method may also be a means of tax fraud, "tax evasion" or collusive 
embezzlement, especially in the case of donation to charities and non-profit organizations.

(4) This method does not contribute to the achievement of tax justice among corporations. It does not achieve fair economic growth for corporations. This method is unfair to shareholders, as it adversely affects shareholders' equity. By deducting the value of donations from the value of taxable income, the value of distributable income to shareholders will decrease. This method may also contribute to a reduction in the market value of the shares of the donor corporations. This method may contribute to the negative or positive impact on the market value of the shares of the donor corporations, depending on the rate of deduction of donations.

(5)This method generates tax savings and therefore the value of donations does not represent real sacrifice incurred by corporations in the context of their interaction with the issues and aspirations of the communities in which they operate.

(6) This method is incompatible with the meanings and contents of the CSR, one of the most important of which is the realization" achievement" of justice in rights among all stakeholders. According to this method, of the most affected parties are the government through the contribution of this method to reduce their tax revenues, and investors by reducing the distributable income due to those donations.

As for the advantages, taking into account the interest of donor corporations without regard to the interest of other parties" stakeholders", donor corporations can achieve economic gains (tax savings) that contribute to enhancing the economic performance of those corporations. Because of these economic gains, this method is considered stimulating for corporations to continue their charitable activities in the communities in which they operate.

2.9.4.2. Secondly: Donations As If They Are Indirect Taxes: Method Of Society's Rights And Then Government's Rights (Tax Exemption In The Sense Of Restoration" Return").

\section{The Disadvantages Of This Method}


In addition to defects No.1 and No. 3 mentioned in the previous method, an additional set of defects that accompanies this method can be identified as follows:

(1) If the restoration" return" rate is less than $100 \%$, this method will contribute to creating a mandatory partnership between the government and the donor corporations. Donations will be funded by government and donor corporations. As well as, the amount of decline in the value of government revenues from taxes (resulting from contributions made by donor corporations) will represent the amount of the government's contribution to those donations, which may be granted to charities and non-profit organizations, which may not directly contribute to the promotion of economic development and infrastructure in the state. As the reduction in government revenues from taxes will not contribute to the promotion of economic development and infrastructure of that country. In addition, this partnership may contribute to creating confusion in the planning of public expenditure in the state and thus change the fiscal policies of government spending.

(2) This method does not contribute to the achievement of tax justice between donor and nondonor corporations. It does not achieve fair economic growth among corporations. This method is unfair to shareholders, as it adversely affects shareholders' equity. By deducting the value of donations from the value of tax invoice" income tax "before the amendment", the value of distributable income to shareholders will increase. This method may also contribute to the increase in the market value of the shares of the donor corporations and reduction in the market value of the shares of the non-donor corporations. This method may contribute to the negative or positive impact on the market value of the shares of the donor and non-donor corporations, depending on the rate of deduction of donations.

(3) This method may contribute to the atrophy and the disappearance of the idea of CSR or loss of the true meaning of the CSR in the field of interaction with the issues and aspirations of society. Especially if the rate of return of donations is $100 \% "$ or that the ratio is sufficiently close to the ratio of $100 \% "$ (The donations will be refunded), as if those who incur those donations are the governments and not the corporations. This method is incompatible with the meanings and contents of the CSR, one of the most important of which is the realization" achievement" of justice in rights among all stakeholders. According to this method, the only aggrieved party is the 
government, through the contribution of this method to reduce their tax revenues.

(4) According to this method, if the value of the returned contributions is less than the actual value of those contributions, the result will be the emergence of what is known as the concept of real sacrifice of voluntary contributions (Total donations - recovered"Restored $\backslash$ Returned" donations $=$ real sacrifice). In addition to the emergence of what is known as the phenomenon of double taxation.

(5) According to this method, shareholders 'equity is affected by the amount of restored " returned" donations. When the return"restoration \retrieval" rate decreases, shareholders' equity will decrease and vice versa. This method may contribute to the negative or positive impact on the market value of the shares of the donor corporations, depending on the rate of return" restoration " of donations. The increase in stock returns resulting from tax treatments does not reflect the real economic performance of corporations. These gains may contribute to an economically unjustifiable increase in the market value of the shares of the donor corporations, and thus make the wrong investment decisions.

As for the advantages, this method achieves the same advantages as in the previous method.

\section{The Method Of Society's Rights And Then Government's Rights "Tax Exemption In The Sense Of Deduction And Tax Exemption In The Sense Of Restoration" Return" Is Inconsistent With The Content Of The Idea Of CSR, For The Following Reasons:}

According to the researcher's point of view, the accurate analysis of this method" Tax Exemption In The Sense Of Deduction" conceals behind it a state of compulsory partnership. CSR is a commitment based on voluntarism in most of its areas. According to this method, donations are voluntarily incurred by corporations, while the government is obliged by law to bear"incur" part of those donations "tax savings resulting from those donations". The researcher believes that this method compels the government to contribute to these donations in a mandatory, non-voluntary 
manner. Where the real sacrifice incurred by corporations- which is less than the real value of donations, means that part of the monetary and in kind donations will be incurred by the government. This mandatory partnership can be inferred through the tax savings that corporations earn as a result of donations, and the decrease in the value of government revenues from taxes resulting from such contributions. CSR does not mean forcing other parties to take part in corporate compliance with their social responsibility towards the communities in which they operate. The tax laws that permit this, are in fact distorting the true meaning of CSR. In the case of "Tax Exemption In The Sense Of Restoration" Return", if the restoration" return" rate is less than $100 \%$, this method will contribute to creating a mandatory partnership between the government and the donor corporations.

The idea of CSR did not appear to exist for economic gain outside the competitive advantage, and it did not come into existence to promote opportunistic behavior and exploit legal loopholes. If this happens, the CSR will lose its true meaning and will deviate from its noble and lofty goals and motives. This method contributes to achieving the tax savings and economic gains-outside the competitive advantage, thus it is incompatible with the content of the CSR idea. As the positive effects of CSR must be achieved through the competitive advantage that can be earned by corporations through their serious commitment to their social responsibility. Those gains" outside the competitive advantage " distort the content of the CSR idea. In other words, those gains will contribute to blurring "obliterating" the supreme meanings of the CSR, make the CSR just a means for economic profits and seizing opportunities through legal loopholes.

CSR is the performance of activities and the achievement of goals in an ethical behavior. The CSR should be above the level of suspicion and uncertainty. CSR as a modern idea is antagonistic to the opportunistic behavior. The CSR is not a means of exporting the administrative failure to other parties, and is not a means of reducing the economic losses of corporations through the exploitation of legal gaps. This method may be a means to achieve that (to export the administrative failure; to reduce the economic losses). This method may be exploited by corporations to get rid of obsolete inventory or inventory whose validity period is nearing completion through the donation to government agencies and bodies or charities, not to interact with the issues and aspirations of the community, but to reduce the economic losses of those 
corporations. Where the government will bear the consequences of administrative failure of corporations and erroneous decisions regarding inventory by allowing tax authority to deduct the value of that inventory from the value of corporations ' revenue or from income tax"initial tax invoice" by type of tax exemption. "Taxable income or income tax"initial tax invoice" will be reduced by the value of that inventory and this treatment will result in a reduction in the value of the tax invoice or the value of the final tax invoice."

CSR is the performance of activities and the achievement of goals in an ethical behavior that fights fraud and circumvention and concealment of information. One of the messages and visions of CSR is an opposition of the fraudulent conduct. CSR is not a means of circumventing and deception. This method, in the absence of a comprehensive disclosure of donations "not to disclose the tax savings and real sacrifice " can contribute to misleading public opinion about those donations. This method conceals what is known as the tax savings and real sacrifice, which are unknown by many people. This is contrary to the principle of transparency in the presentation of data and financial information related to corporate social performance.

One of the contents of the CSR idea is to achieve justice in the field of the rights among all stakeholders. Adopting this method is unfair to the government. It contributes to reducing government revenues from taxes. As well as, this method does not contribute to the achievement of tax justice among corporations. This method also does not achieve tax justice among investors in the corporations.

The idea of CSR is to achieve the goals of the organization in an ethical behavior. It fights corruption and opposes all avenues and factors that contribute to the practice of immoral behaviors. This method is a means for the tax evasion, collusive embezzlement and the export of administrative failure to others " issue of inventory referred to previously."

CSR is an idea above all suspicions. It did not emerge to exist to be within the circle of suspicion and interpretation of intentions by the public and evaluators. The adoption of this method does not reflect the hidden intent behind the incurring of monetary and in kind donations by corporations. Are these donations aimed at interacting with the issues and ambitions of society or are they for the purpose of achieving economic gains outside the framework of competitive 
advantage?. As a result, it is not possible to judge the extent of corporations understanding of the true meaning of their social responsibility towards their societies, as well as to judge the level of their dedication and loyalty to those communities in which they operate.

CSR does not mean to cause harm to the any of the stakeholders. CSR does not mean support for a party and at the same time harming another party. According to this method, the aggrieved party is the government. This method contributes to the reduction of government revenues from taxes and thus reducing its financial ability to meet its obligations.

\subsubsection{Thirdly: Donations As If They Are Not Granted: Method Of Government's Rights And Then Society's Rights.}

\section{The Disadvantages Of This Method}

(1) This method does not achieve tax justice among corporations. As well as, it is unfair to shareholders, as it adversely affects shareholders' equity. Whereas the value of the distributable income will decrease due to the deduction of the value of donations from the value of income" profit" after taxes. This method may contribute to the emergence of so-called double taxation, if donations are considered indirect taxes "according to the vision of the legislature for such donations."AS well as, shareholders will incur such donations as well as tax on distributions.

(2) This method does not achieve any tax savings, so the value of donations will represent the value of the real sacrifice incurred by the corporation. This method reflects the real sacrifice incurred by corporations to fully fulfill their commitments towards the rights of society" donations " and government's rights" income tax ". The value of donations without any tax savings and the value of taxes paid without any tax exemptions. As a result, this may contribute to the reluctance of corporations to continue to make donations.

(3) This method does not contribute to the achievement of tax justice among corporations. This method is unfair to shareholders, as it adversely affects shareholders' equity,when ignoring the value of donations to determine the value of the tax invoice payable to the tax authority. 


\section{Advantages of this method}

(1) According to this method, donations cannot be used as a means of tax evasion, but this method may be a means of embezzling the corporation 's money by corrupt administrations" collusive embezzlement" in case of separation of ownership from the administration. "This method prevents the use of donations as a means to pass some unethical and opportunistic behaviors by corporations."

(2) This method cannot be used as a means of deceiving the public" public opinion" regarding the value of donations made to societies. This method does not contribute to achieving the tax savings, which can contribute to reducing the amount of real sacrifice incurred by corporations. Voluntary contributions will represent the value of true sacrifice. This method is opposed to embrace the policy of circumventing public opinion" The policy of giving "granting" money with the right hand and retrieving the money granted with the left hand."

(3) This method reflects the true intentions of corporations regarding contribution to the development of the communities in which they operate. The obligation of corporations to pay donations, with the use and adoption of this tax method to treat the donations by the tax authority" IRS" will reflect the optimum level of corporate dedication" sincere intentions" to fulfill their social responsibility toward their societies.

\section{The Method Of Government's Rights And Then Society's Rights Is Consistent With The Content Of The Idea Of CSR, But Not Ideally, For The Following Reasons:}

This method will put corporate monetary and in kind donations above the level of suspicions. The sincere intention of corporations to develop their communities and their serious commitment to their social responsibility in the societies in which they operate can be confirmed when this method is adopted by the legislative bodies and applied by the tax authority, and with the continuation of corporations in the donation activities. This situation will reflect the desired ideal position of CSR in the community, especially as corporations realize that no economic gains are made outside the competitive advantage.

This method is consistent with the content of the CSR idea with regard to the achievement of justice in rights" justice in the distribution of rights ". Justice here is in the sense not to harm a party in return for the benefit of another party. The deep meaning of the CSR will impose on 
corporations the need to achieve justice in the field of financial rights between the parties of stakeholders "society and government " in the case of donations to governmental and nongovernmental bodies. Accordingly, government revenues should not be affected by donations paid by corporations. In light of the terrible population explosion and the increase in the burden of government, this method will contribute to support the government in meeting its obligations towards its society without any financial bottlenecks due to the decrease in revenue from direct taxes as a result of these unexpected donations. As the continuation of corporations to make donations despite the application of this method by the tax authority in the State reflects an idealism degree about CSR within the community. Here, it should be noted that both society and government are independent parties in the stakeholder group and both represent an area of CSR areas. Based on this it can be said that, the method of tax treatment that favors a party at the expense of another party will be a breach of CSR's content that calls for the achievement of justice in the distribution of rights.

Regarding equity among investors in corporations or justice among corporations (working in the same field - they have the same market share and economic power), " justice in the distribution of profits or with respect to the rights of the owners ", as noted above, this method does not achieve justice among corporations, and among investors in corporations (because there are some corporations incur those donations and others do not incur), the researcher believes that this issue can not impede adoption of this method for the following reasons: (1) In the presence of the conscious investor, the conscious consumer and active pressure groups in society, corporations will be forced to assume their social role(providing charitable donations). Therefore, the differences among corporations will be close"converging" ; (2) A comprehensive disclosure of the relationship among donations, distribution of profit among shareholders and taxes can contribute to the evaluation of the corporate economic performance in a logical manner by current and prospective investors, thus, according to the researcher's view, this relationship will have no effect on the market value of the shares of the corporations that incur those donations in the presence of aware investors of the importance of CSR in the society; (3) Donations may enhance the competitive advantage of corporations, and thus improving the economic performance of these corporations in the future, and then redeeming any reductions in the rights of owners in the future; (4) The decrease in the amount of income available for distribution as a result of these contributions can be considered a sacrifice offered by investors as a separate entity or an 
independent entity of the corporation to enhance the idea of social solidarity in society and achieve economic development in the country.

CSR means transparency and non-circumvention and this method is fully consistent with this matter. The tax treatment of monetary and in kind donations by using this method will reflect the real sacrifices incurred by corporations towards both the society - through donations in the context of interaction with its issues and aspirations" without achieving any economic gains outside the framework of competitive advantage," and the government through taxes paid without any deductions for those contributions. It is also known that this method does not achieve any tax savings for the benefit of corporations. As a result, there will be no chance of circumventing and deceiving the public about the disclosure" comprehensive disclosure" of such donations. As well as, the policy of circumvention by using the concept of " give by right hand and take by the left hand," which is permitted by law as in other methods. The policy of circumvention cannot be achieved by this method. This method contributes to the promotion of noble and great principles of corporate social responsibility. Donations cannot be used as a way of practicing unethical behavior if this method is adopted, except for collusion embezzlement.

\subsubsection{Fourthly: Donations As If They Are Loans Method Of Government's Rights And Then} Corporation's Rights In Government's Rights.

There are many advantages that this method can offer such as :This method contributes to reducing the impact of legal imbalances in the field of rights to the lowest possible level, unlike the previous methods; This method contributes to strengthening of economic development and infrastructure in the country in a more effective and clear way"under the assumption that, donations will be made to accomplish those purposes, according to the vision on which this method depends" ; This method also contributes to increasing the rate of flow of corporate donations to the public treasury of the state and the growing of the social role of corporations; This method safeguards the content of the idea of corporate social responsibility and contributes to the achievement of an unparalleled harmony between corporate philanthropic responsibility and corporate economic responsibility (by preserving the economic resources of the corporation and contributing to the development of the society in which it operates, at the same time); This 
method contributes to the development of the concept of corporate philanthropic responsibility by moving from the traditional role(donation approach) to the modern role(lending approach).

As for the Disadvantages, if the texts of this law and its articles are not selected in a professional manner and defined in a smart way, and with the influx of large amounts of corporate donations to the State Treasury and the government is committed to returning"pay" installments of those donations to donor corporations, It will be expected that the government will be subjected to financial bottlenecks in future periods due to the decrease in the amount of tax revenues.

\section{The Method Of Government's Rights And Then Corporation's Rights In Government's Rights Is Consistent With The Content Of The Idea Of CSR, Contribute To The Development Of The Concept Of Corporate Philanthropic Responsibility.}

Under the assumption that, donations will be provided to promote economic development and infrastructure in the country- according to the vision on which this method depends, this method will reflect the desired social role of corporations. This method will reflect the real social interaction of corporations with the communities in which they operate. This method safeguards the content of the idea of corporate social responsibility and contributes to the achievement of an unparalleled harmony between corporate philanthropic responsibility and corporate economic responsibility (by preserving the economic resources of the corporation and contributing to the development of the society in which it operates, at the same time); This method contributes to the development of the concept of corporate philanthropic responsibility by moving from the traditional role(donation approach) to the modern role(lending approach).

\section{The Bill" Preliminary Draft Law"}

\section{Corporation As If It Is A Loaner For Government: Optimal Tax Treatment Of Corporate}

\section{Monetary And In-Kind Donations}

Through the previous presentation, it is clear that the Method Of Government's Rights And Then Corporation's Rights In Government's Rights "Donations As If They Are Loans" is much more advantageous than the other three methods. Given the importance of this method, the researcher proposed a bill dealing with the tax treatment of monetary and in-kind donations, which can achieve the following benefits and advantages: Reducing economic damage to donor corporations" impact on market value of shares" ; The protection of the content of idea of 
corporate social responsibility by considering that donations are as subsidies to the community" great harmony between corporate economic responsibility and corporate social responsibility" ; Encouragement of taxpayers to make more donations; To come close to achieving justice in rights between governments and communities looking for greater prosperity; Approaching" getting closer" to a large extent of the case of achieving full tax justice among investors in donor corporations; Eliminating all negative phenomena associated with donation operations through the subjection of those donations to strict control; The Prevention of double taxation.

\section{The Bill" Preliminary Draft Law"}

\section{Corporation As If It Is A Loaner For Government" Donations As If They Are Loans" Optimal Tax Treatment Of Corporate Monetary And In-Kind Donations}

Article (1): Corporate monetary and in-kind donations should be in areas that are subject to government spending in the state such as "supporting government institutions, programs of economic development and infrastructure of the state. These donations are voluntary, and are not compulsory. Article (2): Donations are refunded by deducting them from income tax payable to the tax authority, and not from any other government financial resources. Article (3): Corporate monetary and in-kind donations are under the supervision and control of government in the country. The Ministry of Finance is an intermediary between donor corporations and governmental institutions, organizations and other ministries that benefit from these donations. Article (4): The Ministry of Finance in the State must adhere to the expenditure of voluntary contributions in the fields specified by the donor corporations. The Ministry of Finance is not allowed to spend voluntary funds" cash and non- cash donations" for purposes not specified by the donor corporations. Article (5): The value of donations is deducted from income tax payable to the tax authority in equal installments over five years. This means ignoring the contributions when determining the value of taxable income. Article (6): The support of charities and non-profit organizations is through corporate employees. With the mediation of the Ministry of Finance in the State concerning the receipt and distribution of the values of donations to charities and nonprofit organizations, according to a specific policy. The donation is $\$ 3$ per month from the salary of each employee works for the company. Corporate responsibility is to transfer those amounts to the Ministry of Finance monthly. These donations are mandatory. Article (7): Not to include staff contributions in the list of expenses to be deducted from the revenues of the corporation "ignore those contributions when determining the taxable income." Article (8): Ignoring any donations made by corporations, contrary to what is specified in Article (1) when determining 
the value of the income tax payable or when determining the value of donations that must be deducted from income tax payable to the tax authority. Article (9): After 5 years, the corporation will have recovered the value of those donations. Provided that the income of the donor corporation in those years shall not be less than the income in the year of donation" installments are not deducted in the year in which income is less than income in the year of donation." Ignoring this issue may confuse the government when estimating its tax revenues in future periods. This is what can be called a corporation as if it is a loaner for government. Article (10): All donation activities must be supported by official documents. Article (11): In-kind donations must be estimated at the cost of manufacture or purchase. Article (12): Obsolete inventory" goods" and fixed assets should be estimated at market value. Article (13): Donations made by the donor corporations are in two areas: In the field of promotion of economic development and infrastructure; In the field of spending on government institutions, bodies and organizations. With the need to create a kind of the balance between the two areas.

\subsection{Interpretation Of Preliminary Draft Law " Method Of Government's Rights And Then Corporation's Rights In Government's Rights."}

According to this law, corporate monetary and in-kind donations are for the benefit of public institutions, bodies, organizations and public sector corporations (affiliated to the government ministries), which are funded by the government, which are concerned with providing public services to the general public in the country and also interested in economic development programs and infrastructure development. These donations can be considered as loans to the government that must be recovered or deducted from government revenues. Specifically from the annual taxes levied on those donor corporations over five years. Donations are refunded by deducting them from income tax payable to the tax authority, and not from any other government financial resources. These donations will be under the supervision and control of the State Government. The Ministry of Finance is the authority authorized to receive and disburse such donations in the fields desired" specified" by the donor corporations. This does not mean that corporations are not allowed to donate to charities and non-profit organizations recognized by the government, but these contributions will be ignored when determining income taxes payable to the tax authority. This type of donations is the responsibility of corporate employees to realize the principle of collective responsibility in building contemporary societies. This law aims at supporting governments in the field of economic development and strengthening the 
infrastructure in the country through corporate donations. This law will encourage corporations to donate in the areas of economic development and infrastructure enhancement in the state and makes corporations abandon the support of charities and non-profit organizations that are often in favor of a particular denomination or program and not for the benefit of the general public. The Ministry of Finance in the State is not allowed to spend the funds donated by corporations, except in areas that are specified by those corporations and as they wish. The role of the Ministry of Finance is the mediation between the donor corporations and the governmental bodies and institutions that benefit from such contributions. The role of the Ministry of Finance is a supervision in order to organize of charitable activities. The tax treatment of corporate donations is as follows: For monetary and in-kind donations allocated for economic development and infrastructure enhancement or to cover the expenses of the government or its ministries in certain areas" such as supporting government institutions and bodies" must be deducted from the income tax payable to the tax authority in equal installments over five years, while other donations to charities and nonprofit organizations should be completely ignored. This law does not motivate corporations to donate to charities and nonprofit organizations. The support of charities and non-profit organizations is the responsibility of all employees working in the state in the public sector and the private sector. The support of these charities and non-profit organizations in societies must be provided by all employees in the state in order to promote the spirit of social solidarity and the principle of collective responsibility in building and developing the contemporary societies. Staff contributions should be disregarded when determining income tax payable to the tax authority. These donations must be submitted to the Ministry of Finance, which should be distributed to these charities and non-profit organizations according to a specific policy. All monetary and in-kind donations must be supported by official documents such as payment vouchers, official receipt vouchers, etc. In-kind donations must be estimated at the cost of manufacture or purchase to prevent manipulation and fraud. Donations of obsolete inventory"goods" and fixed assets should be estimated at market value to prevent opportunistic behavior that companies may exercise in order to achieve economic gains to cover up for their failure to manage their economic affairs. A kind of balance must be created between donations in the field of promotion of economic development and donations in the field of spending on government institutions, bodies and organizations to avoid any financial bottlenecks that the government may face in order to meet its future public expenditures(those bottlenecks resulting from its lower revenues). Especially as the government will be committed to returning donations to donor corporations. If all donations are to promote economic development and infrastructure 
with the government's commitment to return donations to donor corporations, the government could face future financial bottlenecks.

\section{Advantages of this method:}

Adoption Of This Law Will Contribute To Achieving The Following Benefits:

(1) In The Field Of Economic Development And Infrastructure Enhancement. According to this law, corporate donations are as loans that must be deducted from the income tax payable to the tax authority. Corporations according to this law will be as if they are lenders to the government. This feature will contribute to increasing the volume of corporate donations and thus provide enormous funds to the government to complete economic development programs and plans and strengthen infrastructure within the country. As all corporate donations will be spent in the areas of economic development and strengthening the state infrastructure.

(2) Regarding the compulsory Partnership between the government and the donor corporations. This law will prevent the state of compulsory partnership between the government and the donor corporations. That partnership imposed by the Method Of Society's Rights And Then Government's Rights, resulting from tax savings achieved" generated" by this method for donor corporations.

(3) Double Taxation. According to this law, corporate donations are as loans that must be deducted from the income tax payable to the tax authority. This law will prevent double taxation, as well as unjustified amplification of income taxes payable, in case the donations are as nonrefundable expenditures.

(4) To Promote The Idea Of Social Solidarity Within Societies. This law reinforces the idea of social solidarity within societies. Corporations through their contributions" loans" will support economic development programs and plans and strengthen infrastructure in the country, while employees working in the private sector and the public sector through their contributions will support charities and non-profit organizations. Building contemporary societies is a collective responsibility. Corporations will be in their interest to donate to government bodies, institutions and ministries because they realize that they will recover the value of these donations" loans" by reducing the amount of taxes imposed on them, and will therefore give up donation to charities 
and nonprofit organizations, and leave room for employees in the state to take full responsibility towards them.

(5) All Donation Activities Are Under Government Supervision And Control. The Ministry of Finance in the State will receive all donations from corporations and provide them to the beneficiaries "governmental bodies, institutions and ministries" as desired by the donor corporations" and therefore all donations will be subject to government control. With this procedure, all the negative aspects associated with the donation activities will disappear.

(6) This Law Will Prevent unethical Practices and behaviours Associated With Charitable Activities Such As Tax Evasion, Money Laundering, Etc. Donations may be a stone for more than a bird "more than a purpose." They may hide behind them many unwanted behaviors in addition to legitimate purposes. The purpose of the donation depends on the intentions of the donor. In general, donations can be a tool to achieve the following purposes: embezzlement, tax evasion, political gains for economic purposes, tax incentives, distracting the attention of the public opinion on a particular issue, to reduce or avoid losses resulting from obsolescence or expiration of inventory,etc. This law will make all corporate donations be subject to strict control which will disappear with it all negative manifestations.

(7) This Law Preserves The Content Of The Idea Of Corporate Social Responsibility. This law does not undermine the freedom of corporations in the field of donations, but regulates its procedures and directs them on the right track. CSR here means contributing to economic construction of societies, as well as maintaining the economic capabilities of corporations "commitment to economic responsibility as well as a commitment to social responsibility towards the communities in which they operate" by supporting economic development and strengthening infrastructure for them. The retrieval of donations does not imply prejudice to the essence of the idea of CSR. Giving money to the government as donations- that can be considered as loans, which are deducted from government revenues from taxes in convenient installments means safeguarding the corporation's finances and supporting communities at the same time. This can be called the harmony between corporate social responsibility (in the economic field) and corporate social responsibility in the field of interacting with the aspirations of the communities in which they operate. This law is against all the immoral practices and manifestations of 
corruption practiced by some corporations, this goal is fully consistent with the content of the idea of corporate social responsibility and its noble principles.

(8) Developing The Concept Of Corporate Philanthropic Responsibility. The proposed bill will contribute to the development of the concept of Corporate Philanthropic Responsibility" changing the philosophy of donations through the shift from the policy of giving to the policy of lending." This proposed law is an attempt to develop the concept of corporate social responsibility by creating a kind of harmony between corporate economic responsibility and corporate philanthropic responsibility. The contribution of corporations to the development of their societies through the promotion of economic development and infrastructure development can be achieved without causing economic damage to those corporations, investors and other stakeholders. These objectives can be achieved by creating a harmony between the economic and Philanthropic responsibilities of corporations without affecting the social performance of those corporations. The support provided by companies can be transformed from the policy of monetary and in-kind donations "donations given and not returned" to the policy of financial support as if it is a loan "loans given and returned." There will be no negative effects on the economic strength of corporations or on economic development programs and plans,and the development of infrastructure in the state or even state tax revenues.

(9) There Is No Significant Impact On The Government's Annual Revenues From Taxes. If this law is adopted, there is no significant impact on the government's annual revenue from taxes. Given that corporate donations- which are considered as loans in this law, will not be deducted from tax income payable to the tax authority at once time but over five years. Thus, the reduction in government's annual revenue from taxes will be little.

(10) This Law Achieves Justice In Rights Among Government, Donor Corporations And Society. The three parties will benefit from this law. According to this law, there is no losing party. Communities will benefit from the gains that will be made by the economic development programs and plans, and the public services that will be provided by the state's advanced infrastructure, which will be financed through corporate donations. Governments will receive financial support from donor corporations to perform their functions and complete of their 
development plans and programs. Donor corporations will recover their funds after five years and therefore they will not lose anything. They will gain consumer loyalty and the satisfaction of the communities in which they operate. Thus, these contributions may contribute to enhancing their competitive advantage.

\section{(11) Reducing Economic Damage To Donor Corporations" Impact On Market Value Of}

Shares." Adoption of this law does not result in achieving tax savings" economic gains" as in other tax treatments "other laws." Not deducting donations from taxable income as in other laws and deducting them from income tax payable to the tax authority - in accordance with this law,will reduce economic damage to donor corporations" impact on the market value of shares" unlike other tax treatments that result in tax savings that vary their values among donor corporations, according to the amount of the donation value, and then the difference in the value of the real sacrifice among the donor corporations. If the value of the donation is high, the value of the tax savings will increase and the value of the real sacrifice will decrease. This will affect the earnings per share. Approaching" getting closer" to a large extent of the case of achieving justice in rights among investors in donor corporations. According to this law, the difference in the earnings per shares of the donor corporations will not be great" will be converging" and thus reduce the damage to the interests of shareholders and the market value of the shares of the donor corporations, that are produced by other tax treatments. In other words, the differences will be less than the differences produced by other tax treatments. The researcher will explain this issue in the language of numbers by using the data mentioned in the previous hypothetical example. Distributed earnings per share for the three corporations are $(\$ 145-\$ 155-\$ 140)$. These values are convergent" the differences are non- significant." Therefore, there will be no impact on the market value of the shares of these corporations due to dividends.

(12) Positive Change In Government Spending Policies. This law will encourage corporations to donate in the areas defined by this law, and governments will receive huge amounts of money from donor corporations. This huge amount of money will make the governments rearrange their policies in the field of government spending and adjust their budgets, especially in the areas of economic development and strengthening the infrastructure in those countries. 
(13) Advance Knowledge" ForeknowledgelPrior Knowledge." This law will help the government to know the amount of decline in its tax revenues in future periods(by knowing the amount of annual installments to be returned to the donor corporations and quarterly activity results for those corporations,) and then take all early measures to address any deficit in the budgets.

\section{The Disadvantage Of This Method And How To Avoid It.}

In case of adoption and application of this law" method of government's rights and then corporation's rights in government's rights" there will be concerns about the decline in government revenues from taxes in future periods because of the accumulation of contributions under the policy of returning these contributions to the donor corporations (the return" recovery of funds" of the installments of those contributions "loans" to the donor corporations). This decrease results in the possibility that the government will be unable to meet its obligations in the area of government spending on its institutions and bodies(In the worst of circumstances, the only drawback expected when applying this law "tax treatment method" is the reduction of government revenues from taxes in future periods. To put it more clearly, what is the extent to which this law contributes to the creation of financial bottlenecks, which may face the government in fulfilling its obligations towards its institutions and bodies. Especially since this law adopts a policy of returning donations to donor corporations ). Factors that may contribute to the occurrence this imbalance are: A significant reduction in revenues of donor corporations in future periods; Lack of reasonable balance between donations In the field of promotion of economic development and infrastructure and donations in the field of spending on government institutions, bodies and organizations. The researcher believes that articles 13;9;4;3;2 will contribute to preventing this problem.

In the case of growth of the revenues of the donor corporations from year to year there will be no significant impact on the state revenues from taxes. As that increase in revenue would be accompanied by an increase in taxes. But in the worst circumstances. In order to avoid this problem, the following guidelines must be observed:

Relocation of the surplus in the budget for the past year as a reserve in the current year's budget to face any decrease in the state revenues from taxes in the current year as a result of the 
return"restoration" of the contributions "donations" to the donor corporations or because of the decrease in revenues of those corporations.

Formation of a reserve in the budget to meet any reduction in the state revenues from taxes as a result of the return of the values of donations "loans" to the donor corporations or because of the decrease in revenues of those corporations.

Donations" loans " must be authorized by the government and in areas that need financial support through the contribution of corporations.

The government should determine the value of the donation" loan " that the donor corporations should make. It is desirable that the values should be small and equal to avoid the negative impact of a decrease in state revenues from taxes as a result of the decline in the revenues of those donor corporations in the future.

Failure to accept any donation requests from corporations regarding the financing of a specific project in the event of obtaining sufficient funding for its completion by corporations.

It is preferable to use the quarterly system in determining the income of the donor corporations after deducting the instalments of the donations that should be returned to those donor corporations. To avoid any financial bottlenecks and try to address them early.

The rate of donation in the field of spending on government institutions, bodies and organizations should be higher than the donation in the field of promotion of economic development and infrastructure. That rate depends on the number of corporations in the state.

\section{What Can Be Considered Logical Answers To The Questions Of This Study}

Through the previous presentation, the researcher can identify short answers to all the questions raised in this study as follows:

Does Granting Tax Incentives " Tax Exemptions" To Donor Corporations Contribute To Enhancing Legal Imbalances In The Field Of Tax Justice And Equity In Rights Among Stakeholders?. 
Yes, it does. Tax incentives do not contribute to achieving tax justice between donor and nondonor corporations; Tax incentives do not contribute to achieving equity in rights among stakeholders, especially between government and society as independent parties in the stakeholder package; Tax incentives do not contribute to achieving equity in rights between shareholders in donor corporations and non-donor corporations; Tax incentives contribute to the creation of a compulsory partnership between government and donor corporations.

What Are The Negative And Positive Economic Effects Resulting From The Granting Of Tax Incentives To Donor Corporations?.

The negative and positive economic effects resulting from the granting of tax incentives to donor corporations are: Enhancing the economic performance of donor corporations by compared to the situation where those donations are ignored "by compared to the tax treatment method that ignores those donations"; The reduction of government revenue from taxes; Tax incentives contribute to enhancing the market value of the shares of donor corporations by compared to the situation where those donations are ignored. Tax incentives urge corporations to donate and thus promote economic development and infrastructure in the country.

Is Granting Tax Incentives " Tax Exemptions" To Donor Corporations Consistent With The Content Of The Corporate Social Responsibility Idea?.

No, it is not. Tax incentives are destructive to the content of the idea of corporate social responsibility. Tax incentives promote the policy of "give by right hand and take by the left hand." This policy is rejected according to the lofty meaning of CSR.

What Are All The Expected Visions About Corporate Donations That Emanates From Them Tax Treatment Methods For Those Donations And, What Are The Logical Justifications Upon Which These Visions Depend?.

Donations as if they are operating expenses(Donations contribute indirectly to improving the economic performance of corporations by gaining the loyalty and satisfaction of employees, consumers, investors and the community, especially in communities that recognize the importance of corporate social responsibility. Donations are the price of survival and continuity of corporations in those communities in which they operate as a result of the depletion of their resources and the export of damages to them.); Donations as if they are indirect taxes (The 
government uses the money earned from corporate taxes to finance public sector expenditures in order to provide services to its citizens, as well as to finance development programs and strengthen the infrastructure in the state, that benefit the public interest. Donations made by corporations to their communities also contribute to the promotion of economic and social development in their countries and contribute to solving many social issues of certain communities in their societies. These donations have a positive impact in field of the service of the common good. Therefore, donations can be considered as indirect taxes provided by corporations to their communities without mediation the government in the process of receiving and re- spending.); Donations as if they are not granted (Donations are expenditures that have nothing to do with the economic activity of corporations. In other words, they do not contribute directly to achieving the profit. Donations are voluntary activities and are not economic activities. These charitable acts should be completely ignored when determining taxable income. Not to ignore these expenditures will contribute to harming the government by reducing its tax revenues. Corporate Social Responsibility (CSR) does not mean giving benefit to a party at the expense of another. Corporate social responsibility means achieving justice among all stakeholders. As is known, donations are often given to non-profit organizations or charities, with the aim of providing assistance to specific communities or to addressing special issues. In this case they are not to support the vital expenditures of the government. ); Donations as if they are loans (Taxes represent government rights in corporate profits. Any obligations paid by the corporation on behalf of the government must be returned to corporation by reducing the value of taxes due to the government. The non-return of these contributions to donor corporations means covering up the government's failure to manage its affairs, including the search for financial resources other than taxes. Corporations must not bear the failure of governments to develop their annual revenues from the diverse sources. Spending on public sectors and government bodies and strengthening the infrastructure of the state is the competence of the government, it is not the competence of corporations. That spending must be financed from taxes or sources other than corporate donations. Although the financing of public sector institutions and the strengthening of the infrastructure in the state in order to improve the public services provided to citizens is a part of the burden, obligations and responsibilities of the government which must be financed from its annual revenues, but corporate donations can be one of the sources of government revenues that can be used to finance those expenditures. Sometimes the governments are unable to finance their public institutions "public spending", as well as funding the process of strengthening the infrastructure in their countries. For this reason, these 
governments resort to stimulate corporations to make more financial contributions to them by using the tax incentive system. These incentives are only evidence of the need for the funds "donations." The corporate donations used to support government spending are only the payment of government obligations on behalf of the government. In this sense, why are not corporate donations considered voluntary loans?. Accurate analysis will show that there is a hidden lending relationship. Pay with your right hand " donations" and take with your left hand" tax incentives." The sacrifice by governments of a portion of their tax revenues for donor corporations suggests that there is a lending process that disappears behind those donations. There is a commitment to donate and there is an obligation to give incentives. This is very similar to the lending process, even if the full amount is not recovered ).

Is There A Real Harmony Between The Expected Visions Of Corporate Donations And The Tax Treatment Methods Derived From Those Visions?.

Yes, there is. Donations as if they are operating expenses (donations are deducted from taxable income ). Donations as if they are indirect taxes(donations are deducted from income tax at a certain percentage, for once at the end of the year). Donations as if they are not granted (donations are completely ignored). Donations as if they are loans (the total value of donations is deducted from income tax in annual installments).

What Are The Comparison Criteria That Can Be Used To Identify The Advantages And Disadvantages Of Possible Tax Treatment Methods Resulting From These Visions And Perceptions?.

There are three criteria that can be used to identify the advantages and disadvantages of possible tax treatment methods for the purposes of differentiation" comparison" among those methods. Those standards are: Economic impact; Legal imbalances; The extent of closeness to, or distance from the content of the idea of corporate social responsibility.

What Is The Optimal Tax Treatment Method That Can Effectively Contribute To The Promotion Of Economic Development And Infrastructure Of The State, Reduction The Legal Imbalances And The Achievement A Kind Of Harmony With The Content Of The Corporate Social Responsibility Idea?. 
The method of government's rights and then corporation's rights in government's rights effectively contribute to the promotion of economic development and infrastructure of the state, reduction the legal imbalances and the achievement a kind of harmony with the content of the corporate social responsibility idea.

What Is The Method Of Tax Treatment That Can Contribute To Achieving A Real Harmony Between Corporate Economic Responsibility And Corporate Philanthropic Responsibility?.

The method of government's rights and then corporation's rights in government's rights safeguards the content of the idea of corporate social responsibility and contributes to the achievement of an unparalleled harmony between corporate philanthropic responsibility and corporate economic responsibility (by preserving the economic resources of the corporation and contributing to the development of the society in which it operates, at the same time); This method contributes to the development of the concept of corporate philanthropic responsibility by moving from the traditional role(donation approach) to the modern role(lending approach).

\section{Recommendations}

The researcher recommends the need to adopt the method of government's rights and then corporation's rights in government's rights due to the many advantages. This method contributes to achieving the following benefits: Promoting economic development and infrastructure in the country in a more effective way; Developing the concept of corporate philanthropic responsibility and shifting from donation approach to lending approach and then creating a kind of harmony between corporate philanthropic responsibility and corporate economic responsibility in order to maximize the social role of corporations in the communities in which they operate(Creating an effective social role for corporations by developing a real and productive interaction between the corporations and their communities); Minimize legal imbalances in the fields of tax justice and justice in the rights to the lowest level.

Regarding the method of government's rights and then corporation's rights in government's rights. In order to achieve the purpose of the law of this method, which is to increase the volume of the flow of funds to the State Treasury to implement the plans and programs of economic development and infrastructure enhancement, governments should identify all projects to be implemented in future periods, and that need funding and support from the private sector in that country. In this regard, the government can rely on propaganda and advertising programs. The 
need to issue the articles of this law in a professional manner to avoid any problems that this law may cause in future periods such as financial bottlenecks.

\section{Conclusion}

From the point of view of the legislative bodies and according to their philosophy and vision, corporate monetary and in-kind donations can reflect one of the following scenarios" perceptions":Donations are considered as expenditures that should be included in the expenditure list in the income statement; Donations are considered as indirect taxes that must be deducted from income tax; Donations are expenditures that should be disregarded when determining the value of the income tax; Donations are considered as loans to the government and must be returned to the donor corporations. Based on these perceptions, tax treatments emerge to reflect the tax law. In other words, tax treatments ( tax laws) adopted by governments are a reflection of these perceptions.

This theoretical study showed the disadvantages of the methods of tax treatment of monetary and in-kind donations and their negative effects in the field of achieving tax justice among the taxpayers, "the donor and non-donor corporations." In addition to not achieving tax justice among the investors in the donor and non-grant corporations, and the double taxation issue accompanying those tax treatments if donations are considered as indirect taxes. The study also showed that one of these treatments" the method of society's rights and then government's rights" does not achieve justice in rights between governments and communities as independent parties in the stakeholder package. As well as, this study pointed out that one of these treatments" the method of government's rights and then society's rights " preserves the content of the idea of corporate social responsibility, but not ideally, and this method may prevent the negative phenomena associated with donation activities such as tax evasion, etc. While the method of government's rights and then corporation's rights in government's rights includes many disadvantages. For this reason, this method is ideal. As a result of this deficiency in those three laws" tax treatments", this study proposed a draft law for the tax treatment of monetary and inkind donations by using the method of government's rights and then corporation's rights in government's rights (as a perfect method) as an initiative that can contribute to overcoming these tax problems and the negative phenomena associated with corporate donations. The draft law proposed in this study depends to a large extent on argument and logical justifications. The search for a wonderful approach through which real and productive interaction can be created between corporations and their communities in which they operate is still ongoing. This 
approach, which can contribute to the achievement of huge achievements in the field of economic development and infrastructure in the country will remain a concern for all those interested in the field of corporate social responsibility. The researcher believes the method of government's rights and then corporation's rights in government's rights will contribute to achieving this end.

\section{REFERENCES}

Al-Kholi,Asma(5 December 2015).Donations by America's billionaires: Are they donations or tax avoidance? ".Al-Sharq Al-Awsat.https ://aawsat. com/ home/ article/511811 /

Al Rai Newspaper . (2011, 18November).The private sector calls for legislation to stimulatethe adoption of the idea of CSR . From .http:// alrai.com/ article/ 681515 .html

Avi-Yonah, R,( 2014 ). Just Say No: Corporate Taxation and CSR, Public Law and Legal Theory Paper series no. 402 University of Michigan.from file:/// C:/Users/ ECSK/Downloads/SSRN-id 2423045.pdf

Bertrand,Marianne,Bombardini,Matilde, Fisman, Raymond and Trebbi, Francesco .( 2018 ) . TaxExempt Lobbying: Corporate Philanthropy As a Tool for Political Influence . January 11, 2018.from https:// law.yale. edu/system /files/area/ workshop /.../ leo18_fisman.pdf

Canada Revenue Agency: Charities Directorate( n.d.). Tax Advantages of Donating to Charity. https:// www.cchwebsites. com/content/pdf/tax_forms/ca/en/rc4142_en .pdf

Carroll, Archie B. (2016). Carroll's pyramid of CSR: taking another look.International Journal of Corporate Social Responsibility. 1:3.pp1-8.https://jcsr .springeropen .com /track/pdf/ 10.1186/s40991-016-0004-6

Dattani, P., Still, A., and Pota, V. (2015). Business backs education: Creating a baseline for corporate CSR spend on global education initiatives. Business backs education. Retrieved September 23, 2016, from http://businessbackseducation.org/ research/

Egyptian Tax Authority (n.d ). Income Tax Law No. 91 of 2005 http:// www . incometax.gov.eg.

Enders, Bob ( n.d ).Tax Incentives: An Economic Basis for Charitable Giving.from https://www.learningtogive.org/resources/tax-incentives-economic-basis-charitable giving.

Fack, Gabrielle and Landais, Camille( May 2010 ).Are Tax Incentives for Charitable Giving Efficient?Evidence from France. American Economic Journal: Economic Policy 2 (May 2010): 117-141.

General Commission For Taxes And Feesin Syria ( n.d). Income Tax LawNo. 24 of 2003.http: //www.syriantax. gov.sy/print_details.php?page= show_det \&id $=149$

Charitable giving guide( 2017).Helping to maximise donations to the wider community September 2017.https://www.pwc.ie /publications/2017 / charitable-giving-guide.pdf

Grigore, Georgeta ( 2010 ). Ethical and Philanthropic Responsibilities in Practice. Annals of the University of Petroşani, Economics, 10(3), 2010, 167-174. https:// www.upet.ro/ annals / economics/pdf/2010/20100317.pdf 
Henderson, M. Todd and Malani A .(2008). Corporate Philanthropy and the Market for Altruism. The Law School The University Of Chicago, John M. Olin Law and Economics Working Paper No. 399.

JA Worldwide ( n.d.). Giving Back-Corporate Philanthropy and Social Investing, Session 10.from https: //www.juniorachievement .org/documents /20009/1187253 /High School10.pdf

John, Rob , Chia, Audrey and Ito, Ken.( 2017 ). Corporate Philanthropy in Asia Innovations that Unlock the Resources of Business for the Common Good. Entrepreneurial Social Finance in Asia: Working Paper No. 5 Asia centre for social entrepreneurship \& philanthropy.NUS.from https://bschool.nus.edu .sg/Portals/ 0/images/ACSEP/Publications/acsep-working-paper-no5-e book . pdf.

Kasipillai, Jeyapalan and Rachagan, Shanthy ( 2012 ). Tax Incentives and Corporate SocialResponsibility International congress on Innovation and Regional Economic Development which took place on the 2nd - 4th December, Hefei,China.

Keeler, D.( 2002 ). Spread the love and make it pay. Global Finance , 5:16, p. 20 -25.

Lordemus, Samuel ( 2013 ). Evaluating the efficiency of the tax incentives toward corporate philanthropy. Master's thesis. Paris School of Economics. The University of Paris 1. Panthéon Sorbonne.

Lyons, M. and Passey, A. (2006) 'Need Public Policy Ignore the Third Sector ? Government Policy in Australia and the United Kingdom', Australian Journal of Public Administration, 65

M. Scilly( n.d.). Four Types of Corporate Social Responsibility.From: http: // small business .chron.com/four-types-corporate-social-responsibility-54662 .html

Madrakhimova, Firuza S.(2013). Corporate Philanthropy. Global Conference On Business And Finance Proceedings . Volume 8 . Number 2.pp125-132.Online :http://old. uona.edu/UoNA /files /literature / 3231.2634_ISSN-1941-9589-V8-N2-2013 _c.pdf

Man ,Theresa L.M. ( September 18,2006 ). Corporate Giving : A Tax Perspective. Paper available online: www .carters .ca/pub/ article/charity /2007/tlm_ corpgiving.pdf

McGregor-Lowndes, Myles, Newton, Cameron and Marsden, Stephen (2006).Did tax incentives play any part in increased giving?. Australian Journal of Social Issues.22 Dec.2006. $41,(4) ., 495-509$

Ministry of Finance \General Secretariat of Taxation "Sultanate of Oman"(2017). Amendment to the Tax Code" under Royal Decree No. 9/2017.https:// tms. taxoman.gov.om /portal/ar /web / taxportal / news /-/asset_publisher/V05zDAqSo Mrz / content/id/83184

Mihaljevic, Marija and Tokic, Ivana ( 2015). Ethics and Philanthropy in the Field of Corporate Social Responsibility Pyramid. Interdisciplinary Management Research, Josip Juraj Strossmayer University of Osijek, Faculty of Economics, Croatia, vol. 11, pp 799-807.

Nell,Christopher(n.d.). Tax Evasion and Charitable Giving-An Experimental Approach.From :https ://pdfs.semanticscholar.org/bec2/dd7713c3dcc4ef4c43b49494a06098b710bc.pdf

Perry, Suzanne ( 2006 ). Giving by Companies Rose 14\% Last Year, Study Finds" The Chronicle of Philanthropy, June 15, 2006; Fleishman-Hillard Research and National Consumers League: "Rethinking Corporate Social Responsibility" (Fleishman-Hillard Research and National Consumers League, 2006) (online: http:// www .csrresults .com). 
Porter, Michael E and Kramer, Mark R. (2002).The Competitive Advantage of Corporate Philanthropy, Harv. Bus. Rev. 80(12): 56-68

Saleh,Younis A. Battal( May 2018).Arguing about the tax saving and real sacrifice resulting from the hypothetical comparison of non-mandatory social expenditures : A theoretical study to enrich and develop disclosure of the corporate philanthropy and income tax law. Journal of Business \& Economic Management 6(5): 79-89.

Saleh,Younis A. Battal( 2019). Tax Treatment Methods of Corporate Monetary and in-Kind Donations and the Extent of their Compatibility with the Content of the Idea of Corporate Social Responsibility: A Justified View. Austin Journal of Business Administration and Management .3 (1):1-15.file: /// C:/ Users/ECS-K/Downloads/ fulltext_ajbam-v3-id1034 $\% 20$ (6). pdf

Sudaress (2013). Donations for Taxes.https://www.sudaress.com/alintibaha/29759

Svernlöv,Carl ( 2016 ). Corporate Social Responsibility and Corporate Taxation .from https:// www.svensktnaringsliv .se/migration_ catalog/ Rapporter _och _ opinionsmaterial /Rapporter / corporate _social_report_webbpdf_666655.html/BINARY/Corporate_Social_report_webb.pdf

Wyk, LJ Van( 2011). Corporate Social Responsibility (Csr): A Theoretical Overview. Chapter Three .From http:// dspace.nwu. ac.za/bitstream/ handle/ 10394/8531/Van _Wyk_LJ _Chapter_3.pdf ? sequence $=4$ 